\title{
Revize středního opevnění na Staré Kouřimi
}

\section{Revision of knowledge about the central fortification at Stará Kouřim}

\section{Daniel Dvořáček}

\begin{abstract}
Abstrakt
Raně středověké hradiště Stará Kouřim je po rozsáhlém archeologickém výzkumu vedeného $M$. Šollem ve 40.-50. letech 20. století považováno za jedno z nejdůležitějších opevněních center $\checkmark$ Čechách v době před uchopením vlády Přemyslovci v první polovině 10 . století. Od skončení výzkumu uběhlo již více než 60 let. Pưvodní interpretace je třeba znova prověřit. Zároveň velké množství poznatků zůstalo dodnes nezpracováno. Předkládaný článek se věnuje výzkumu střední hradby, jedné ze tři hlavních linií opevnění, která byla odkryta na více místech, ne vždy jí však byla věnována patřičná pozornost. V článku jsou prezentovány hlavní výsledky nového revizního zpracování této nesporně zajímavé fortifikace.
\end{abstract}

\section{Klíčová slova}

raný středověk, hradiště, Stará Kouřim, revize, opevnění

\begin{abstract}
Archaeological excavations of the early medieval fortified stronghold at Stará Kourim, conducted by $M$. Solle in the 1940s-1950s, revealed that this stronghold represented one of the most important fortified centres in Bohemia before the rise of the Premyslids in the first half of the 10th century. More than 60 years have passed since the excavations were finished and the original interpretations have to be verified. Moreover, a great deal of knowledge still needs to be analysed and evaluated. This article is dealing with excavation of the central defensive wall, one of the three main fortification lines. This structure was uncovered at multiple places but it did not always earn proper attention. The article presents the main results of a new revision of knowledge about this significant fortification.
\end{abstract}

\section{Key words}

Early Middle Ages, fortified stronghold, Stará Kouřim, revision, fortification 


\section{1. Úvod}

Hradiště Stará Kouřim, jehož nejvýznamnější období je kladeno do druhé poloviny 9. až první třetiny 10. století, přitahuje stále značnou pozornost odborné veřejnosti, k čemuž také napomáhá skutečnost, že je tu kladeno sídlo regionální elity, a navíc je tato lokalita jako jedna z mála známa jménem již v 10. století, kdy byl v Kristiánově legendě zmíněn souboj sv. Václava s vládcem Kouřimi (Kristián, c. 10, 100-103). V letech 1948 až 1957 se na toto hradiště zaměřil rozsáhlý archeologický výzkum pod vedením Miloše Šolla (obr. 1). Výsledná monografie „Stará Kouřim a projevy velkomoravské hmotné kultury v Čechách“ byla vydána devět let po skončení výzkumu (Šolle 1966). Jak už název napovídá, publikace byla zaměřena především na nejzajímavější objevy vhodné k prezentaci, zatímco mnoho podstatných údajů je dosud obsaženo jen v nálezových zprávách a stále čeká na zpracování. V nedávné době byly některé starší výzkumy podrobovány kritické revizi, napřriklad středočeská hradiště Budeč (Bartošková 2014) či Libušín (Varadzin 2012). Revize zasáhla také opevnění Pražského hradu (Boháčová 2001). Revizní výzkumy a nové vyhodnocení opevnění bylo provedeno na Pohansku u Břeclavi (Dresler 2011) a v Mikulčicích (Hladik a kol. 2014; Mazuch 2014). Nově bylo revidováno povelkomoravské opevnění Starých zámků u Lîšně (Kalčık 2015). Předložený příspěvek se věnuje reviznímu zpracování odkryvů střední hradby, které bylo založeno především na práci s dostupným materiálem (plány, fotografie, nálezové zprávy, keramika) a je zatím prvním takovým zpracováním pro Starou Kouřim ${ }^{1}$.

\section{Stručný přehled a vývoj lokality}

Stará Kouřim se rozprostírá v zemědělsky příznivé oblasti na rozlehlém návrší s nejvyšším bodem o nadmořské výšce 294,2 m. Na severní i východní straně terén pozvolna klesá do okolní mírně zvlněné krajiny, zatímco jižním a západním směrem prudce spadá do údolí říčky Výrovky. Návrší bylo pro svou výhodnou polohu využíváno k sídlení i pohřbívání od pozdního neolitu až po raný středověk. Nejstarší raně stř̌edověké nálezy, známé však z druhotné polohy, jsou spojovány již s kulturou pražského typu. Zhruba od počátku 9. století se Stará Kouřim postupně začala rozvíjet jako opevněný útvar, kdy byla na pozůstatcích opevnění malého hradiště řivnáčské kultury postavena nová hradba a byl vydělen tzv. vnitřní areál (akropole). Někdy v druhé polovině 9 . století byl opevněný útvar rozšíŕen o střední areál (1. předhradí) se střední hradbou a následně i o vnější areál (2. předhradí) s vnější hradbou. Na přelomu 9. a 10. století mělo dojít k vyplenění Staré Kouřimi, přičemž dřevohlinitá střední hradba zanikla požárem. Počátkem 10. století byla vybudována nová stř̌ední hradba, opatřená čelní kamennou zdí. Stará Kouřim zanikla v druhé čtvrtině až polovině 10 . století, patrně v souvislosti s vytvářením českého státu a s tím souvisejícím podmaňováním nepřemyslovských oblastí Čech Boleslavem I. Kouřim však neztratila na významu a nejpozději v 11. století bylo založeno nové správní centrum s kostelem sv. Jiří na protější ostrožně (Šolle 1966, 99-109, 175-181, 227-228; 1969a; 1993).

\section{Opevnění Staré Kouřimi}

Následující popis opevnění shrnuje poznatky získané M. Šollem (1966, 33-34, 99-109, 137, 175-181, obr. 18-25, 33, 35-36, 45-47). Opevněný útvar je podle průběhu fortifikace rozdělen do tří areálů - vnitřního, středního a vnějšího. Nejmenší vnitřní areál o rozloze 4,8 ha v jižním cípu návrší v nejlépe chráněné poloze byl opevněn vnitřní hradbou dlouhou 400 m. Střední areál měl rozlohu 14,8 ha a byl 


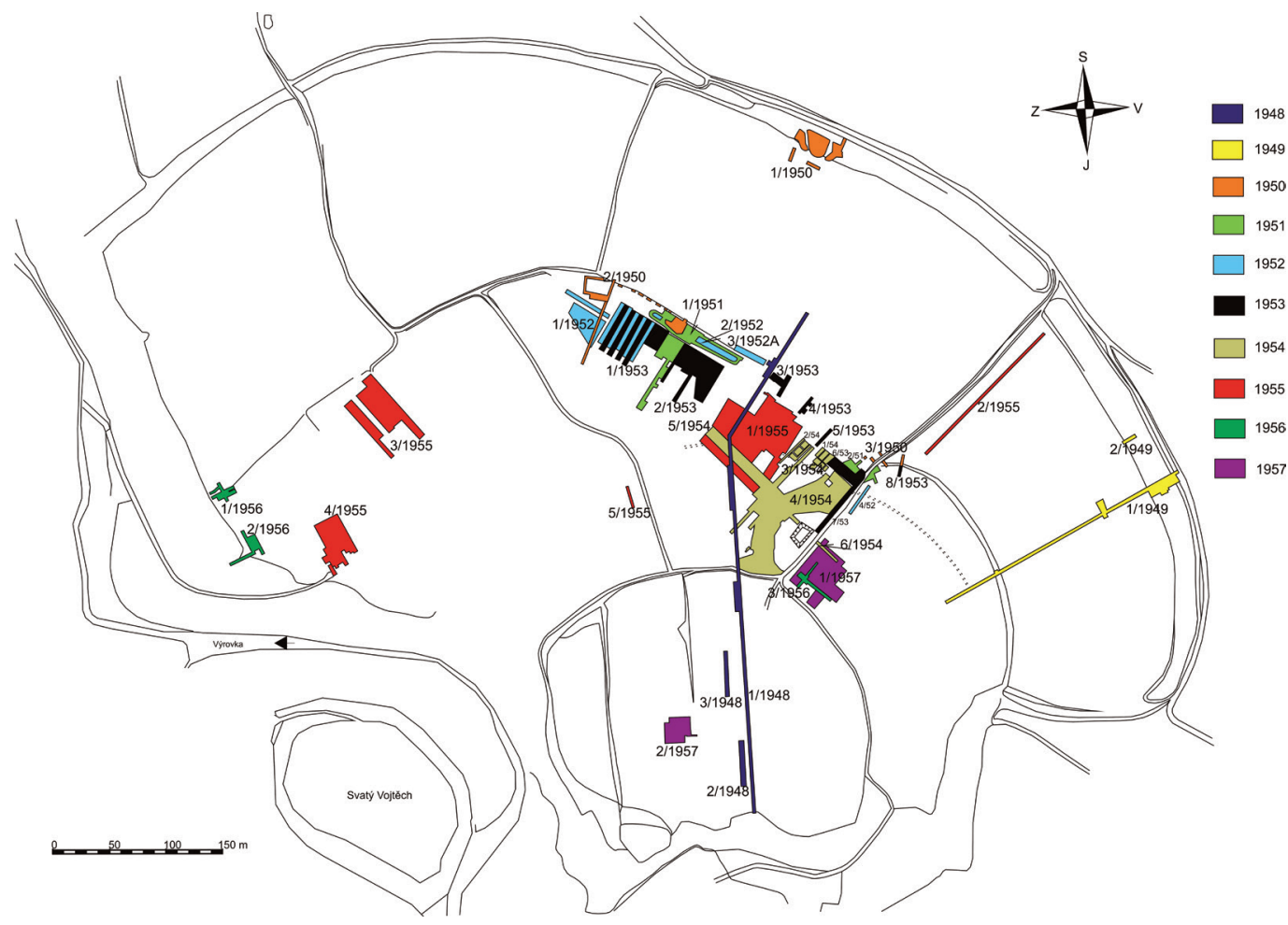

Obr. 1. Stará Kouřim - plán lokality znázorňující rozsah archeologického výzkumu 1948 až 1957. Barevně jsou od sebe odlišeny jednotlivé sezóny (Archiv AÚ AVČR Praha, upraveno).

Abb. 1. Alt Kouřim - der Plan der Anlage mit Grabungen 1948-1957. Die Kampagnen sind voneinander farblich unterscheidet (Archiv AÚ AVČR Praha, modifiziert).

opevněn střední hradbou o délce $820 \mathrm{~m}$. Nej- vé opevnění bylo doplněno jižní vnějšrí hradbou větší vnější areál zahrnuje plochu 24,6 ha a byl v současné době v terénu téměř neznatelnou, opevněn vnější hradbou dlouhou $1320 \mathrm{~m}$. De- která chránila lokalitu nad strmými svahy do strukce vnější hradby je dodnes v rámci lokality nejlépe zachovanou fortifikací a dosahuje výšky 3 až $4 \mathrm{~m}$. V současné době jsou hradby patrné v podobě valů, které tvoří tři rovnoběžné obloukovité perimetry nad těžce př́stupným srázem na jihozápadě, jihu a jihovýchodě (obr. 2). Destrukce opevnění byla bohužel na Staré Kouřimi v minulosti značně snižována, v některých úsecích až téměř zlikvidována jako nežádoucí bariéra bránící zemědělské činnosti². Obvodoúdolí Výrovky. Je třeba také zmínit menší příkop ve středním areálu, který měl snad původně sloužit jako vymezení zamýšleného malého předhradí před vnitřním areálem a opevnění chránící prostor u Libušina jezírka, které rozdělilo stř̌ední areál na západní a východní část.

Archeologickým výzkumem byly odkryty také pozůstatky tř́ bran (Šolle 1953b; 1966, 104-109, 179, 181, obr. 21-25; 1969b). Př́stup po cestě od Výrovky zajištovala jižní brána. Do 


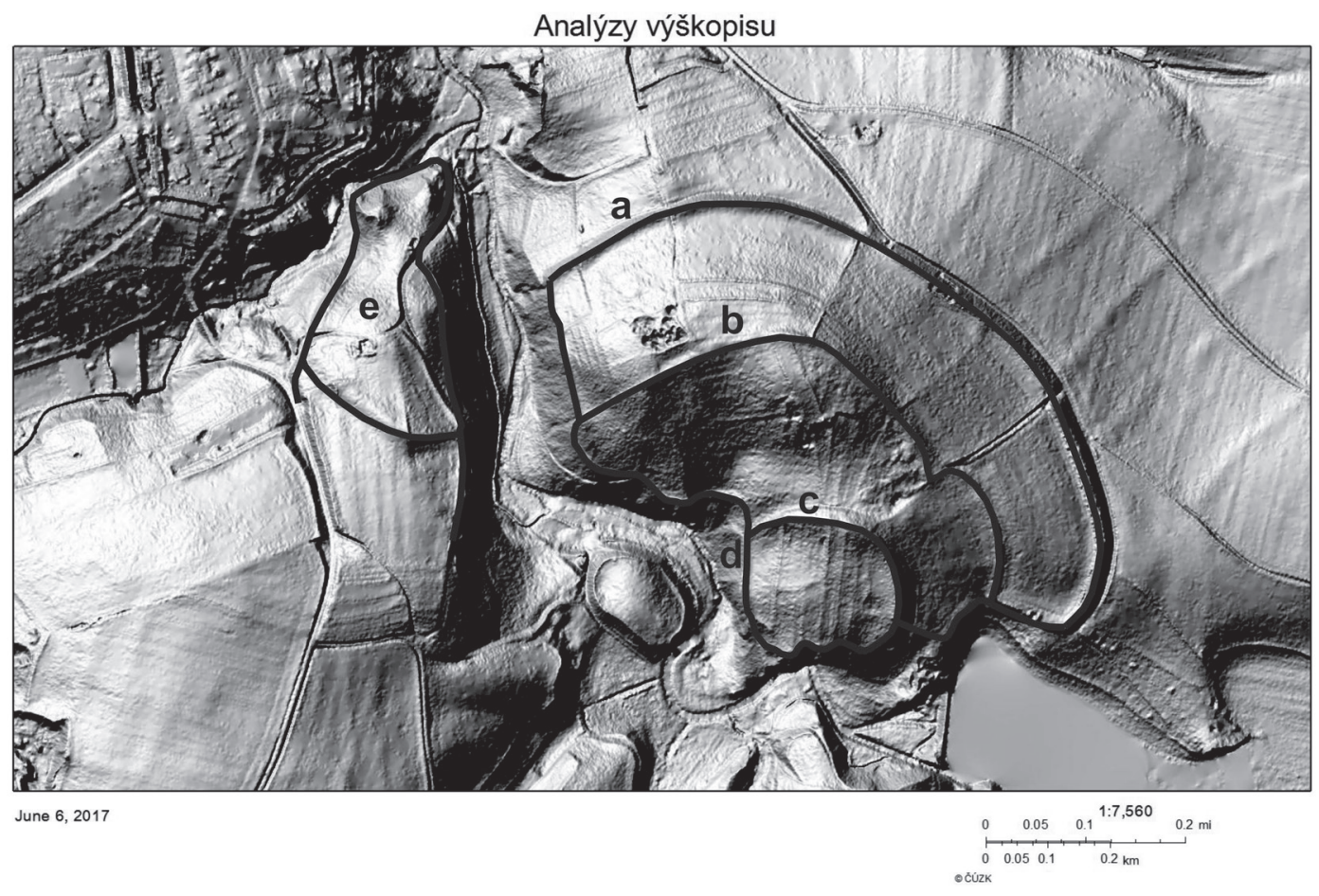

Obr. 2. Plán lokality se zvýrazněným průběhem opevnění. A - vnější hradba, b - střední hradba, c - vnitřní hradba, d - jižní vnější hradba, e - Kouřim sv. Jiří (zdroj dat ČÚZK).

Abb. 2. Plan von Alt Kouřim und Umgebung. Befestigungsanlagen sind hervorgehoben. A - der äußere Wall, b - der mittlere Wall, c - der innere Wall, d - der südliche Außenwall, e - Kouřim - St. Georg (Quelle ČÚZK)

středního areálu se vcházelo tzv. střední branou a vstup do vnějšího areálu zajištovala dvoukřídlá vnější brána se dvěma průchody. Další bránu bychom zajisté mohly hledat také v linii vnitřního opevnění, které je však jen minimálně prozkoumané. Celý opevněný areál Staré Kouřimi zahrnuje 44,2 ha. Svým rozsahem se tak řadí mezi největší české i středoevropské opevněné lokality raného středověku.

\section{Střední hradba}

\subsection{Průběh střední hradby a okolnosti jejího výzkumu}

Destrukce střední hradby o délce přibližně 820 $\mathrm{m}^{3}$ je nejlépe prozkoumanou a bohužel také po jižní vnější hradbě nejvíce poničenou linií opevnění na Staré Kouřimi (obr. 3; tab. 1). Na západním i jihovýchodním konci musela být tato fortifikace nějakým zatím nezjištěným způsobem napojena na jižní obvodovou hradbu. Pro zjednodušení prostorového odlišení zkouma- 
a)

b)

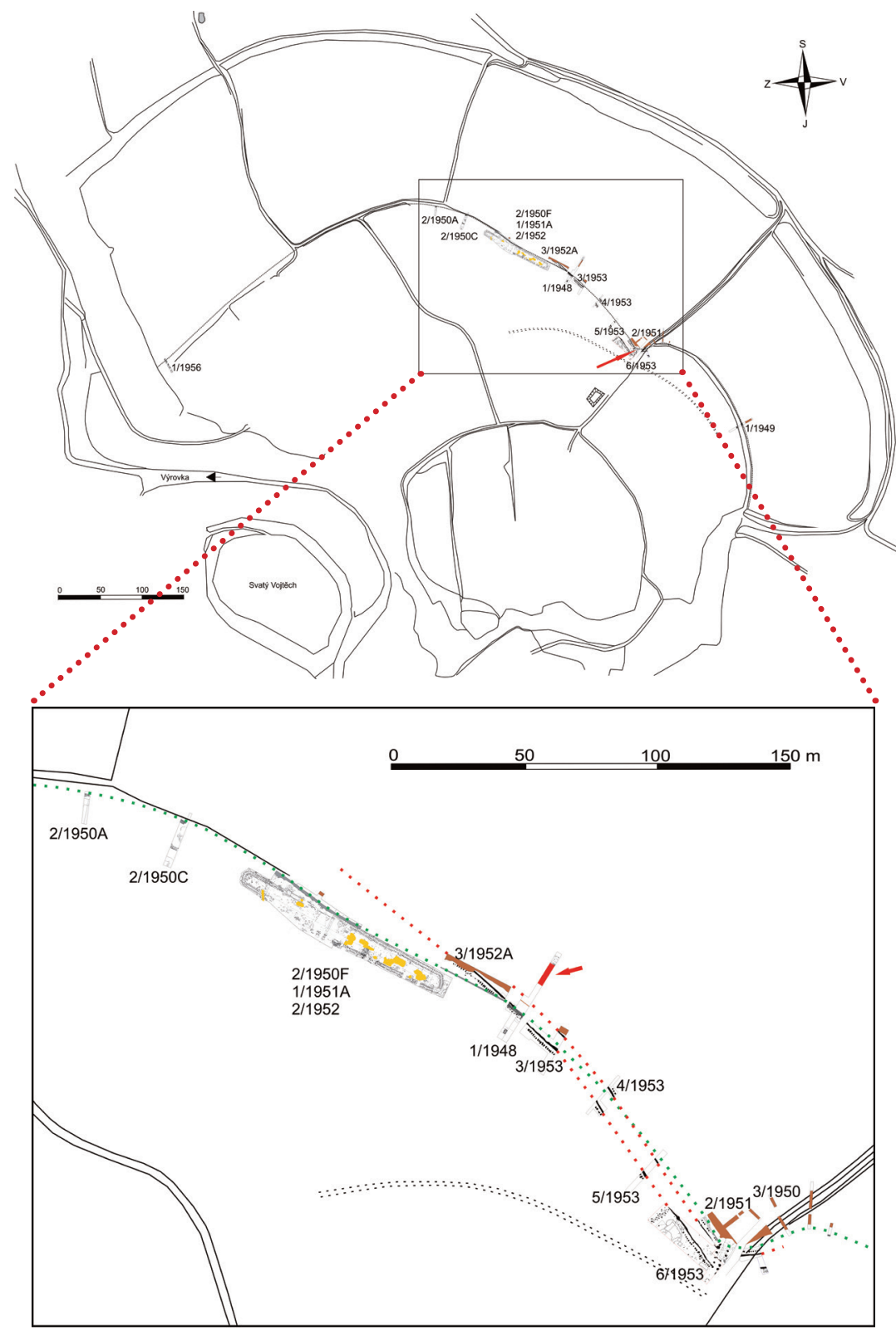

Obr. 3. a) Stará Kouřim - na plánu jsou zachyceny sondy, které zasáhly destrukci střední hradby. Poloha střední brány je označena šipkou. Obdélník - podrobněji zachycený střední úsek linie středního opevnění (viz. obr. b); b) Červená tečkovaná linie - průběh starší hradby, směrem na západ je průběh nejasný. Červená šipka ukazuje zachycený starší přikop. Zelená tečkovaná linie - průběh mladší hradby. Hnědá barva - sondami zachycený mladší príkop.

Abb. 3. a) Alt Kouřim - auf den Plan sind die Schnitten gefast, die durch den mittleren Wall geführt wurden. Der Pfeil zeigt die Toranlage. Das Rechteck - im Detail gefasste Abschnitt der Befestigung (siehe Abb. b); b) Die rote Punktlinie - der Verlauf des älteren Walles, in Richtung nach Westen ist der Verlauf unsicher. Der Rotpfeil zeigt, wo der ältere Graben neuidentifiziert wurde. Die grüne Punktlinie - der Verlauf des jüngeren Walles. Braun - der durch Schnitten freigelegte jüngere Graben. 
ných částí střední hradby jsem její průběh rozdělil na tři úseky ${ }^{4}$ - západní, střední a východní.

Západní úsek (délka: přibližně $330 \mathrm{~m}$ ) byl z větší části dříve zplanýrován a dnes je již těžko okem patrný. Směrem od západu prochází destrukce opevnění v délce asi 130 m dnes stěží prostupným hustým keřovitým porostem. Hustý porost střídá travnatá louka, kde pokračuje průběh opevnění po hřebeni až téměř k nejvyššímu bodu, před nímž se fortifikace začíná náhle zvedat a zde již začíná úsek střední. Západní úsek byl zkoumán v jeho nejzápadnější části sondou 1/1956 (Šolle 1957, 1-6), která měla odhalit napojení střední hradby na hradbu jižní. Velkoplošnou sondou 3/1955, která byla založena za účelem poznání osídlení prvního předhradí západně od vrcholu návrší, byla odkryta jen malá část týlu hradby (Šolle 1956, 42-43, 46). V západním úseku zhruba $\mathrm{v}$ jeho polovině prováděl výkopy i J. L. Píč (1907, 519-526, obr. 2).

Střední úsek (délka: přibližně $370 \mathrm{~m}$ ) je nejvíce prozkoumaným úsekem destrukce středního opevnění. Táhne se od nejvyššího bodu Staré Kouřimi s novověkou kapličkou, kde se destrukce hradby výrazně zvedá, a dále sleduje hřeben návrší, který klesá směrem východním ke střední bráně. Úsek končí v místě, kde byla zjištěna zmíněná brána a kde dochází k výraznému zalomení průběhu opevnění. Destrukce hradby je nejlépe patrná v nejvyšším místě návrší se zmíněnou kapličkou a v západní části jejího průběhu, kde lemuje z vnější strany ovocný sad. Pozvolna se však destrukce snižuje tak že v druhé polovině je patrná jen v mírné terénní vlnce. Úsek byl zkoumán prakticky po celé jeho délce sondami 2/1950 A-F (Šolle 1951, 10-18), 1/1951a (Šolle 1952, 4-5, 10-13), 2/1952 (Šolle 1953a, 15-22), 3/1952 A (Šolle 1953a, 22-25), 1/1948 (Šolle 1949, 9-11), 3/1953 (Šolle 1954, 18-21), 4/1953 (Šolle 1954, 21-22) a 5/1953 (Šolle 1954, 22-23). Mezi středním a západním úsekem v ostrém zalomení průběhu destrukce opevnění je linie přerušena relikty střední brány. Ta byla odkryta sondami 3/1950 1-7 (Šolle 1951, 18-20), 2/1951 (Šolle 1952, 13-14), 4/1952A (Šolle 1953a, 27-28) a 6/1953 (Šolle 1954, 23-28; obr. 4).

Východní úsek (délka: přibližně $290 \mathrm{~m}$ ) představuje nejlépe zachovalou část průběhu střední hradby. Táhne se od brány do středního areálu a končí při východním svahu Staré Kouřimi nad zaniklým rybníkem Strašíkem, kde by se měl napojovat na destrukci jižní vnější hradby. Destrukce opevnění je v tomto úseku zarostlá hustým keřovitým porostem. Kameny v líci valu mohou být pozůstatky čelní kamenné zdi. Úsek byl zkoumán především dlouhou sondou 1/1949 (Šolle 1950, 7-9) a malými sondami 3/1950 8 (Šolle 1951, 21) a 8/1953 (Šolle 1954, 30).

První zásah do destrukce střední hradby učiněný s úmyslem poznání hradiště Stará Kouřim byl proveden již J. L. Píčem (1907, 519-526, obr. 3). Hradbu zkoumal v západním úseku, kde popsal výskyt „zuhelnatělých trámců“, které byly kladeny podélně a příčně. Největší množství odkryvů destrukce střední hradby souvisí však až s výzkumem M. Šolla (tab. 1). V prvních dvou letech výzkumných prací (1948-1949) byly kladeny několik set metrů dlouhé sondy skrz celý opevněný areál. Střední hradba byla odhalena ve dvou kompletních profilech včetně příkopu (sondy 1/1948 a 1/1949, obr. 9, 11). Účel těchto zjištovacích sond spočíval v možnosti vytvořit si základní představu o charakteru osídlení a fortifikaci Staré Kouřimi. V letech 1950-1953 byly v rámci výzkumu již více pokládány sondy za účelem odhalení zajímavých situací vhodných k prezentaci. $\mathrm{V}$ nejvyšším místě návrší ve středním úseku byla sondáží marně hledána destrukce střední brány. Místo ní však došlo k objevu pozoruhodné konstrukce, která byla po postupném odkrývání interpretována jako tzv. halová stavba. Výzkum této zvláštní stavby, která se nacházela přímo pod mladší fortifikací, pokračoval další dva roky. Bohužel zvolený 


\begin{tabular}{|c|c|c|c|}
\hline Sonda & Úsek & $\begin{array}{l}\text { Celý řez } \\
\text { vč. př́kopu }\end{array}$ & Hlavní účel založení sondy \\
\hline $1 / 1948$ & střední & Ano & $\begin{array}{l}\text { Dlouhá sonda, stanovení charakteru osídlení a fortifikace } \\
\text { hradiště. }\end{array}$ \\
\hline $1 / 1949$ & východní & Ano & $\begin{array}{l}\text { Dlouhá sonda, stanovení charakteru osídlení a fortifikace } \\
\text { hradiště. }\end{array}$ \\
\hline 2/1950 A-F & střední & $\mathrm{Ne}$ & Hledání brány do středního areálu. \\
\hline 3/1950 1-8 & střední/východní & $\mathrm{Ne}$ & Hledání a identifikace brány do středního areálu. \\
\hline $1 / 1951$ & střední & $\mathrm{Ne}$ & Navázání na sondu 2/1950 F, objev tzv. halové stavby. \\
\hline 2/1951 & střední/východní & $\mathrm{Ne}$ & Výzkum vnější části střední brány. \\
\hline 2/1952 & střední & $\mathrm{Ne}$ & Výzkum tzv. halové stavby - dokončení. \\
\hline 3/1952 A & střední & $\mathrm{Ne}$ & $\begin{array}{l}\text { Kontrolní sondy, objasnění „fošnových základů” odkrytých } \\
\text { sondou 1/1948, identifikace starší hradby. }\end{array}$ \\
\hline 4/1952 A & střední & $\mathrm{Ne}$ & Výzkum hradby při střední bráně. \\
\hline 3/1953 & střední & $\mathrm{Ne}$ & Stanovení poměru mezi starší a mladší hradbou. \\
\hline $4 / 1953$ & střední & $\mathrm{Ne}$ & Výzkum nově identifikované starší hradby. \\
\hline $5 / 1953$ & střední & $\mathrm{Ne}$ & Výzkum nově identifikované starší hradby. \\
\hline $6 / 1953$ & střední/východní & $\mathrm{Ne}$ & Dokončení výzkumu střední brány. \\
\hline $8 / 1953$ & východní & $\mathrm{Ne}$ & $\begin{array}{l}\text { Ověření pokračování starší fáze hradby východně od střední } \\
\text { brány a její poměr k mladší fázi hradby. }\end{array}$ \\
\hline $3 / 1955$ & západní & $\mathrm{Ne}$ & $\begin{array}{l}\text { Rozsáhlá sonda založena kvůli zjištění charakteru osídlení . } \\
\text { Zasáhla však okrajově destrukci střední hradby. }\end{array}$ \\
\hline $1 / 1956$ & západní & $\mathrm{Ne}$ & $\begin{array}{l}\text { Stanovení průběhu střední hradby a jejího napojení na jižní } \\
\text { obvodovou hradbu. Sonda vybrána také jako místo s vyšším } \\
\text { výskytem fosforu. }\end{array}$ \\
\hline
\end{tabular}

Tab. 1. Přehled sond, kterými byla odhalena destrukce střední hradby.

Tab. 1. Der Übersicht der Schnitte, durch die der mittleren Wall freigelegt wurde.

způsob odkrývání této stavby byl proveden bez ohledu na destrukci hradby, kdy sonda 1/1951 A byla rozšiřována především za účelem sledování půdorysu stavby, zatímco jádro destrukce hradby bylo tímto bez patřičné pozornosti částečně prokopáno až na úroveň pásu sloupových jamek, které tvořily půdorys tzv. halové stavby. Po nalezení správné polohy střední brány v ostrém zalomení průběhu opevnění východně od vrcholu návrší došlo $\mathrm{k}$ její postupné exkavaci. V letech 1952 a 1953 byla identifikována a následně otevřením nových sond $(3 / 1952$, 3-5/1953) zkoumána starší střední hradba.
Tato výzkumná fáze (1950-1953) již měla konkrétnější cíle, než ta předchozí na sklonku 40. let, a došlo plošně k největším odkryvům tělesa střední hradby. V letech 1954-1957 byly aplikovány nové př́rodovědné metody - fyzikální metoda odporová a fosfátová půdní analýza ( $P e-$ likán - Vojáček 1956). Podle výsledků fosfátové analýzy byly dokonce pokládány sondy na místa s bohatým výskytem fosforu. To se týkalo také sondy 1/1956, kterou byla zkoumána stř̌ední hradba při styku s jižní vnějš́ hradbou v blízkosti ostrých svahů do údolí Výrovky. Zájem o poznání střední hradby byl v rámci výzkumu 
lokality odsunut spíše na okraj a větší pozornost si zasloužily „nejzajímavější“ objevy jako brána do vnějšího areálu se dvěma vstupy, jež byla v terénu rekonstruována (Šolle 1953b), pozoruhodná tzv. halová stavba, a především bohaté pohřebiště u Libušina jezírka (Šolle 1959; 1966, 147-166). Při této skutečnosti není překvapivé, že kompletní řezy střední hradbou i s příkopem máme jen z prvních dvou sezón výzkumu (1948 a 1949), kdy byly pokládány především dlouhé zjištovací sondy.

\subsection{Dosavadní představa o podobě střední hradby}

Dosavadní představa o podobě a vývoji střední hradby vychází z práce M. Šolla (1966, 101-102, 108-109, 175-179, obr. 19, 23-24, 45-46). Při archeologickém výzkumu byly zjištěny dvě fortifikace - starší a mladší. Přímo ke starší hradbě z vnitřní strany přiléhal zvláštní útvar, který byl interpretován jako tzv. halová stavba (Šolle 1966, 109-113). Stavba měla zaniknout současně se starší fortifikací a př́ímo na destrukci tzv. halové stavby byla založena mladší hradba.

\subsubsection{Starší hradba}

Podle terminologie R. Procházky měla starší fáze střední hradby podobu skořepinové konstrukce se dvěma dřevěnými stěnami, snad propojenými dřevěnými kleštinami (Procházka 2009, popisek k obr. 42:1). Vnější a vnitřní dřevěné stěny byly tvořeny palisádami $\mathrm{z}$ fošen, které byly vloženy do předem vyhloubených žlabů, hlubokých přibližně 80 až $90 \mathrm{~cm}$. Obě stěny byly navíc zvenčí podepřeny šikmými vzpěrami. Vzpěry zvyšovaly hradbě stabilitu, z vnější strany však nepůsobily z hlediska obrany zcela vhodně. Vlastní těleso hradby bez vzpěr dosahovalo šíŕky $6,5 \mathrm{~m}$ a v blízkosti střední brány 5,5 m. M. Šolle se pokoušel odhadnout přibliž- nou výšku hradby, kdy vycházel ze sklonu dochovaných vzpěr. Ty se s hradebními stěnami protnuly v přibližné výšce $2 \mathrm{~m}$. Podle tohoto údaje autor výzkumu odhadl výšku hradby na $3 \mathrm{~m}$ a s předprsní až na $4 \mathrm{~m}$. Předprseň pravděpodobně vznikla protažením vnější stěny do výšky. Prostor mezi oběma hradebními stěnami byl vyplněn hlínou a stěny byly pravděpodobně propojeny dřevěnými kleštinami. Před hradbou se zřejmě nacházel i příkop, který měl být později kompletně zahrnut do širokého příkopu mladší hradby. Vstup do středního areálu zajištovala střední brána, umístěná v místě ostrého zalomení průběhu středního opevnění. Vchod brány byl hluboký 8 metrů a směrem od vnějšku se zužoval z 2,7 metru na 1,5 metru. Obě boční stěny vchodu byly zpevněny pěti sloupy. Nad branou stála pravděpodobně i věžová nástavba a do brány vedla mírně zahloubená cesta štětovaná drobným kamením (obr. 4, 5). Zánik fortifikace lze pravděpodobně přičíst „náhlé katastrofě“, při které zanikly požárem střední hradba, brána a tzv. halová stavba, zatímco vnější hradba zůstala zachována (Šolle 1966, 175).

\subsubsection{Tzv. halová stavba}

S průběhem staršího opevnění souvisí také konstrukční relikt, interpretovaný jako tzv. halová stavba. Tento útvar byl $89 \mathrm{~m}$ dlouhý a až $10 \mathrm{~m}$ široký, oba konce - východní i západní - byly polokruhovitě uzavřeny. Tzv. halová stavba se nacházela v zákrytu starší dřevohlinité hradby při jižním svahu těsně pod nejvyšší částí návrší. V místě zmíněné stavby došlo rovněž k odkryvu skupiny zahloubených objektů (obr. 6). Objekty, které zasahovaly do obvodu stavby byly datovány jako pravěké či raně středověké, předcházející její výstavbě, zatímco ty jámy, jež jí respektovaly a nacházely se v její východní části, byly dávány do souvislosti se stavbou jako jakési sklípky. Jejich prŕítomnost ovlivnila M. Šollem vyslovený předpoklad, že halová stavba byla roz- 


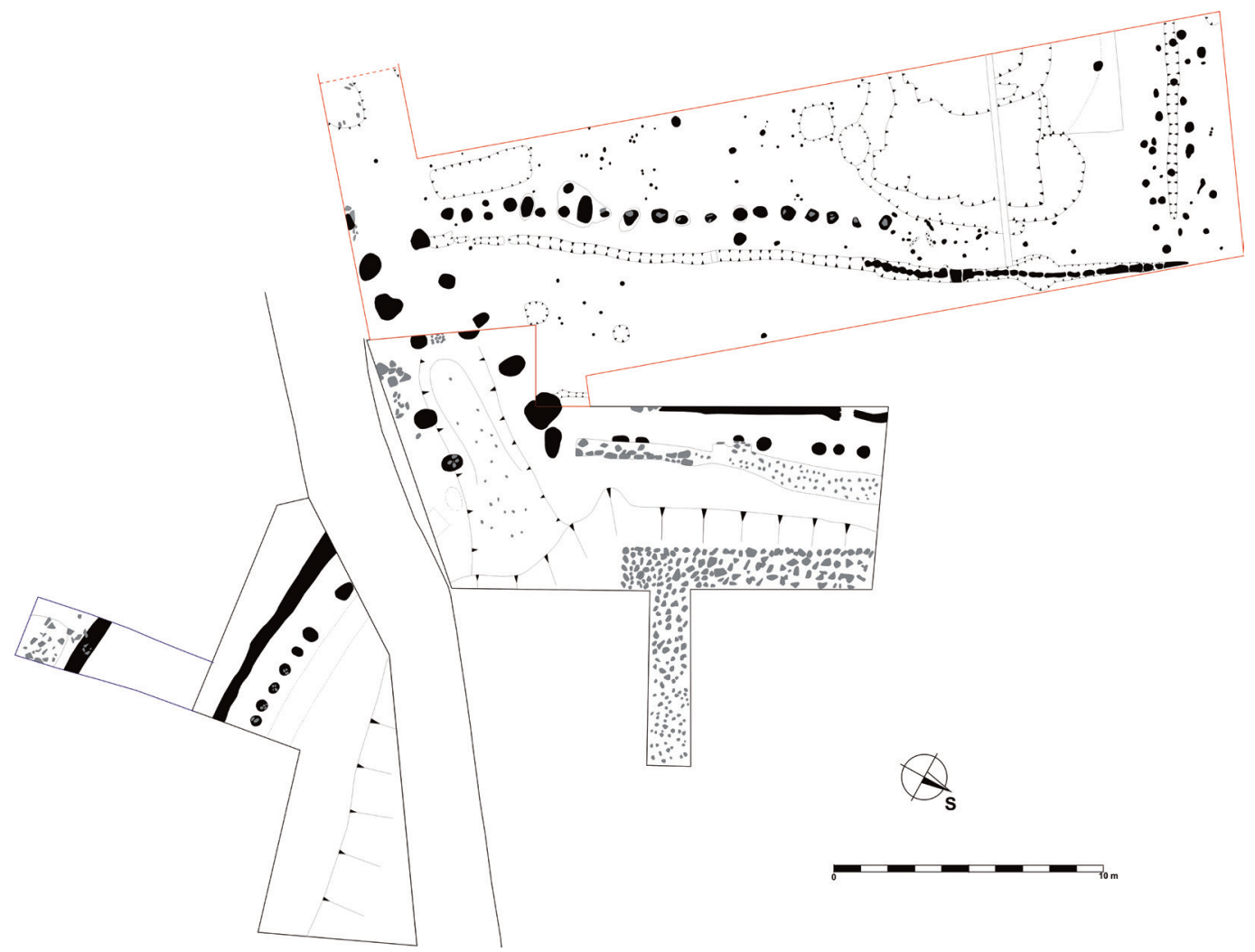

Obr. 4. Střední brána, půdorys odkrytých situací. Černé ohraničení sonda 2/1951, červené ohraničení sonda 6/1953, modré ohraničení sonda 4/1952 A (Archiv AÚ AVČR Praha, upraveno).

Abb. 4. Das mittlere Tor, der Grundriss der freigelegten Flächen. Schwarze Begrenzung: der Schnitt 2/1951, rote Begrenzung: der Schnitt 6/1953, blaue Begrenzung: der Schnitt 4/1952 (Archiv AÚ AVČR Praha, modifiziert).

dělena na dvě poloviny, západní plochou a východní s jamami. Každá polovina by tak měla sloužit odlišným účelům, západní ke sněmům a k různým slavnostním př́ležitostem, zatímco východní se sklepními jamami měla být určena k obývání.

\subsubsection{Mladší hradba}

Mladší hradba byla založena převážně na reliktech starší hradby. Pouze v nejvyšším místě návrší došlo k mírnému zkrácení jejího průběhu, kdy byla postavena prŕmo nad zbytky tzv. halové stavby a relikty staršího opevnění pohltil nový př́kop. Za bývalou tzv. halovou stavbou M. Šolle předpokládal návrat průběhu mladší fortifikace do trasy starší hradby (Šolle 1966, obr. 5). Vnější příkop dosahoval hloubky až 4,5 m a šířky až $9 \mathrm{~m}$. Mezi př́íkopem a čelní kamennou zdí se nacházela asi $3 \mathrm{~m}$ široká berma. Hradba byla zepředu opatřena kamennou zdí stavěnou z místní ruly a zadní část uzavírala menší kamenná zídka. Těleso hradby je rekonstruováno jako stupňovité směrem od jejího čela k týlu. V místě rozsáhlého plošného odkryvu nad destrukcí tzv. halové stavby byly také identifikovány komory 


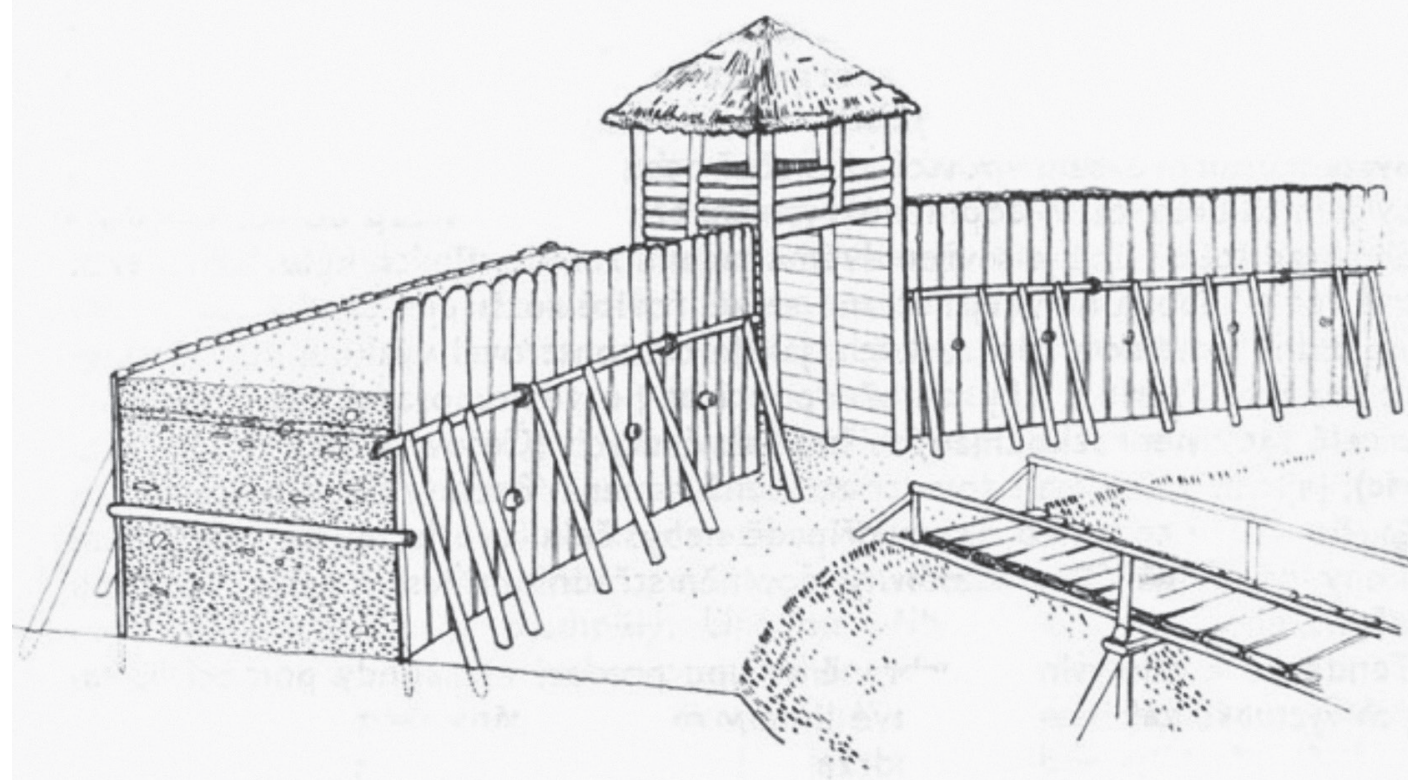

Obr. 5. Rekonstrukce starší hradby a střední brány (Šolle 1966, obr 24).

Abb. 5. Die Rekonstruktion des älteren Walles und des mittleren Tores (Šolle 1966, Abb. 24).

široké přibližně 5 až 6 metrů. Ty od sebe oddělovaly přepážky z kamenů a pravděpodobně i z dřevěných trámů. Jednotlivé komory pak byly prokládány rošty překládkovým způsobem. M. Šolle předpokládal, že překládkový způsob kladení roštů byl použit jen $\mathrm{v}$ nejvyšší poloze návrší, zatímco ve zbylých částech průběhu střední hradby výztuž tvořil jednosměrný rošt. Hradba dosahovala širŕky 8 metrů a v nejvyšším místě návrší až 10 metrů. Z mladší brány, která se pravděpodobně nacházela na stejném místě jako brána starší, se nám bohužel vlivem novověkého „rozvážení valů“ nezachovalo zcela nic. Rovněž mladší hradba byla podle terminologie R. Procházky (2009, popisek k obr. 42:2) skořepinové konstrukce, zdokonalená o dvě kamenné zdi a roštovou výztuž obousměrné varianty (obr. 7).

\subsection{Analýza řezů $2 / 1952,1 / 1948$ a 1/1949}

\subsubsection{Rez 2/1952}

Řez pochází z plošného odkryvu tzv. halové stavby, jejíž půdorys byl zjištěn pod destrukcí mladší hradby a který byl odkrýván s pomocí sond 2/1950F, 1/1951A a 2/1952. Řez 2/1952 (obr. 10; popisky vrstev tab. 2) byl narušen starší 2,5 m širokou sondou 1/1952, kterou byly odkrývány obvodové stěny stavby, zatímco sondou 2/1952 byl odhalen zbytek jejího půdorysu. V řezu jsou zachyceny sloupové jámy (505), které jsou relikty po severní a jižní stěně stavby. Sloupové jámy byly zahloubeny do sprašového podloží. Snad ještě před zánikem halové stavby vznikla vrstva 133 . Destrukce mladší hradby byla tvořena souvrstvím popela a spraše (135), sprašovou vrstvou 136 a popelovitou vrstvou 138. Ve vrstvách 136 a 138 byly zachyceny dvě 

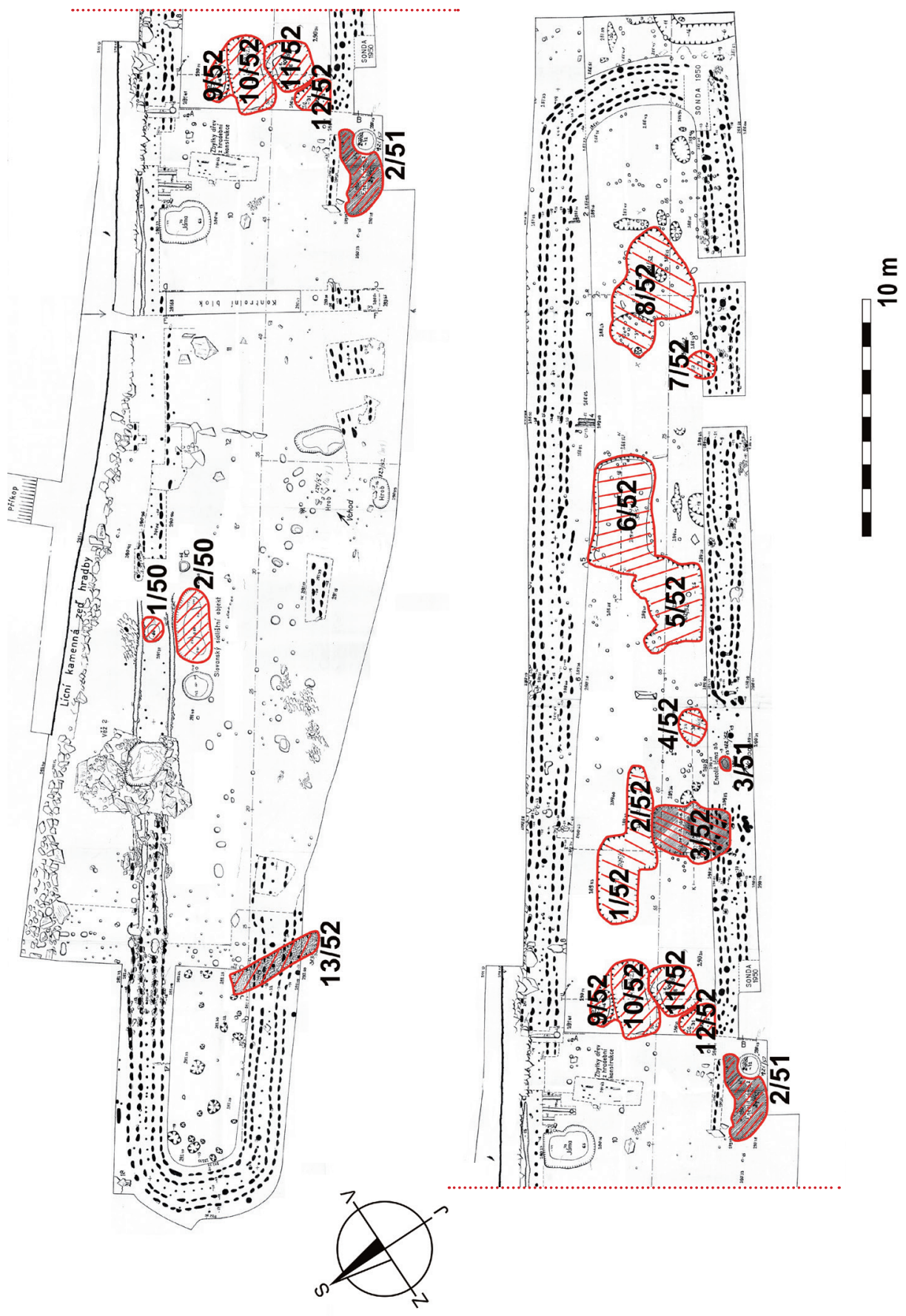


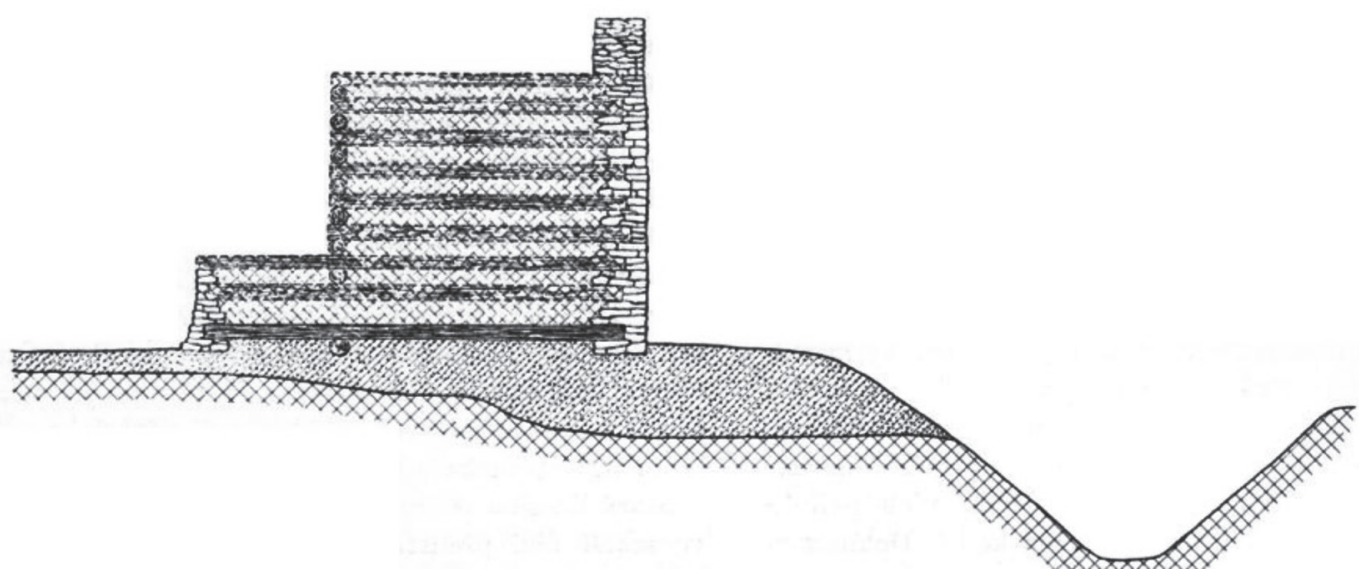

Obr. 7. Rekonstrukce mladší hradby (Šolle 1966, obr. 45).

Abb. 7. Die Rekonstruktion des jüngeren Walles (Šolle 1966, Abb. 45).

vrstvy roštové výztuže. Vpředu stojí torzo čelní kamenné zdi (900), která byla postavena na hlinité vrstvě 134 . Prostor $3 \mathrm{~m}$ široké mírně klesající bermy a vnitřní strany př́kopu byl zasypán kamennou destrukcí z čelní zdi (139), blíže k povrchu s příměsí spraše (140, 141). Příkop byl odkryt pouze částečně. Destrukce týlu hradby byla tvořena hlinitokamenitou sutí s uhlíky (142), jejíž vzdálenost od líce čelní zdi činila přibližně 8,5 m. Zarážející je překrytí vrstvy 135 vrstvou 142. Pokud vrstva 135 skutečně náležela již k mladší hradbě, mohla by být vrstva 142 pozůstatkem stupňovitého týlu hradby.

\subsection{2. Řez $1 / 1948$}

Tento řez destrukcí střední fortifikace, který se nachází v jejím středním úseku, byl odkryt v prvním roce výkopových prací na Staré Kouřimi v rámci dlouhé zjištovací sondy 1/1948. Na východním profilu i na půdorysu můžeme pozorovat relikty starší i mladší hradby a hrotitý příkop (obr. 8, 9; popisky vrstev tab. 2). Ze starší hradby byl zachován především vnitřní žlab s otisky fošen po palisádě (503), který dosahoval hloubky přibližně $80 \mathrm{~cm}$ a byl vyplněn hnědou humózní zeminou s opálenými kousky dřev (108). Vnitřní žlab byl zahlouben do sprašového podloží (100) a do vrstvy černohnědé zeminy (101), na kterou nasedala bělošedá jílová vrstva (102). Vrstva 102 byla zřejmě starší než hradba, před žlabem byla však zakreslena rozděleně. Zřejmě se jednalo o dvě vrstvy podobného charakteru, z nichž ta vrchní mohla být součástí starší hradby. Sprašová vrstva 103 snad již pocházela z tělesa starší hradby. Spálená vrstva 104 (sprašová červenožlutá promíšená se zetlelým a spáleným dřevem a s úzkými popelovitými žilkami) pravděpodobně představuje pozůstatky shořelé a vně rozvalené vnitřní palisády spolu s hlinitou výplní jádra hradby. Sonda 1/1948 byla zasazena do polohy, kde je patrné odchýlení mladší hradby od staršího opevnění (obr. 3a, 3b). Proto nepřekvapí, že destrukce mladší hradby se zde jen částečně kryje s hradbou starší. Jádro mladší hradby představuje sprašová vrstva 105 rozdělená lehce se svažující úzkou popelovitou vrstvou 106. Vrstva 106 pravděpodobně představuje zbytek podélného spáleného břevna roštu. Dřevěný rošt byl zajisté propojen s čelní nasucho kladenou kamennou 

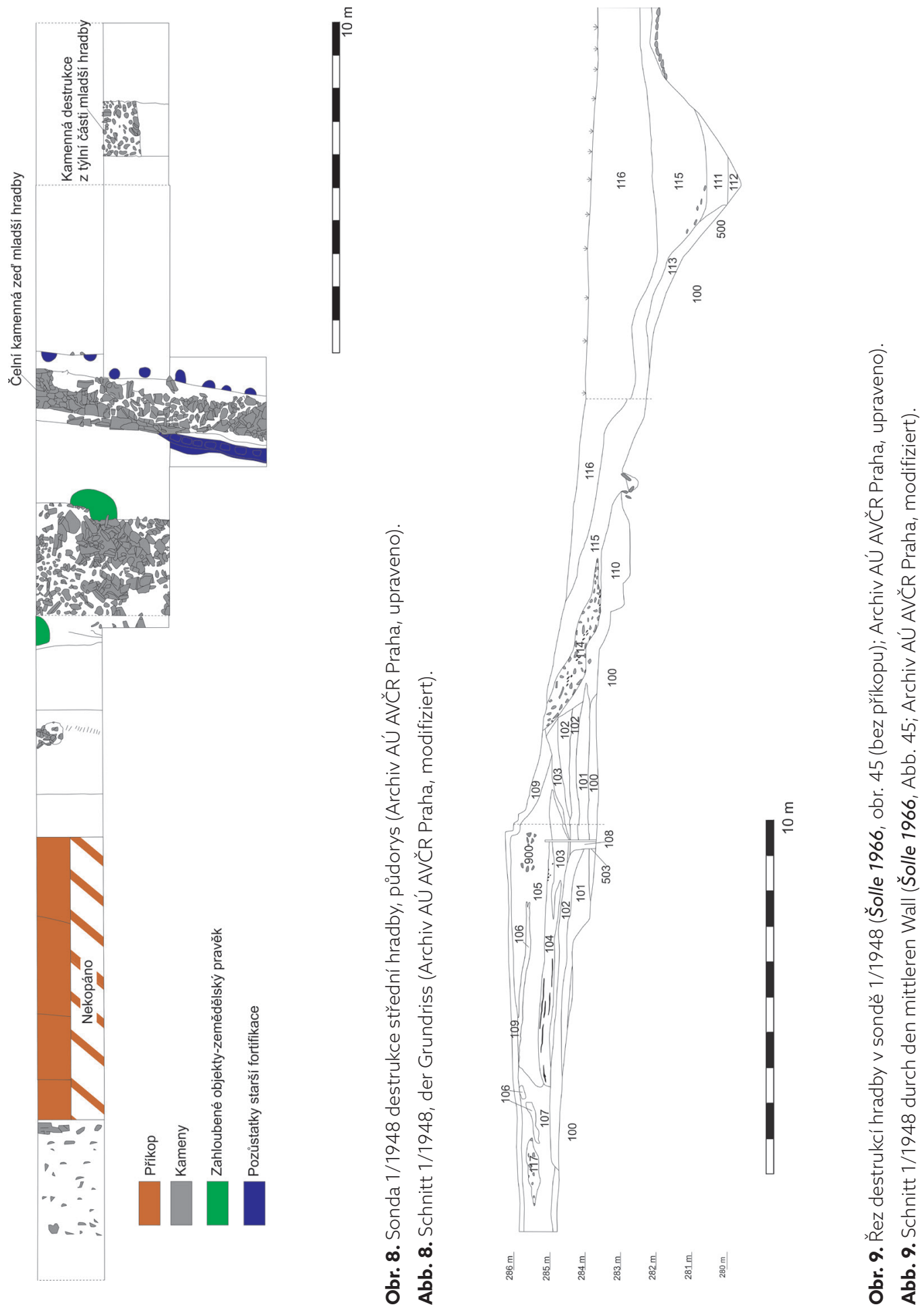
zdí, která je označena číslem 900 . Torzo zdi zde dosahovalo výšky až $70 \mathrm{~cm}$ a šíŕky kolem $1 \mathrm{~m}$. Ve východním profilu je zed' jen málo patrná, lépe je zachycena na fotografiích (např. Šolle 1966, tab. XXX:2). Špatně zachovalá destrukce týlní části byla tvořena sprašovou vrstvou 107, která zřejmě pocházela $\mathrm{z}$ rozvaleného jádra hradby, kamennou destrukcí 117 a úzkou popelovitou vrstvou 106 (snad zbytek břevna roštu). Týlní část hradby je v tomto místě široká přibližně $4 \mathrm{~m}$ a od čelní kamenné zdi je vzdálená asi $7 \mathrm{~m}$. Před destrukcí staršího i mladšího opevnění byl zachycen hrotitý prríkop. Jeho šířka dosahovala přibližně $9 \mathrm{~m}$ a hloubka asi 2,5 $\mathrm{m}$ od původní úrovně terénu, vnější okraj byl obložen kameny. Z hlediska rozpadu opevnění jsou důležité vrstvy 110 (sprašová, snad původně část výplně jádra starší hradby, podobného charakteru jako vrstva 103), 114 (kamenná destrukce z čelní zdi), které byly nakonec převrstveny hlinitými zeminami 115 a 116, čímž definitivně zanikl příkop. Zarážející je značná vzdálenost př́kopu od kamenného líce mladší hradby, která činí až 13 m. Čelní kamenná zed' zde byla postavena na destrukci zadní stěny starší hradby. Domnívám se, že hrotitý příkop již náležel starší fortifikaci. Vezmeme-li v úvahu, že starší hradba byla široká $6 \mathrm{~m}$, byla šířka bermy mezi hradbou a př́kopem 7 až $8 \mathrm{~m}$ (oproti 13 m v případě mladší hradby). Vrstvy 101, 102 a 103 byly přerušeny novým výkopem (později zaplněným vrstvou 110), který měl zřejmě nahradit vnitřní stranu příkopu. Starší hrotitý prríkop zůstal stále nezasypán a spolu s rozšířenou vnější stranou vznikla až $19 \mathrm{~m}$ velká bariéra. Mezi vnitřním okrajem takto velkého příkopu a čelem hradby se vytvořila asi $3 \mathrm{~m}$ široká berma.

\subsection{3. Řez 1/1949}

Řez byl získán z východního úseku průběhu střední fortifikace, východně od střední brány. Sonda 1/1949, ze které pochází západní profil (obr. 11; popisky vrstev tab. 2), byla podobně jako 1/1948 dlouhá zjištovací. Destrukce starší hradby se zachovala v podobě vnějšího (502) i vnitřního žlabu (503), vzdálenost mezi žlaby je přribližně $6,5 \mathrm{~m}$. Po dřevěné palisádě zůstal v obou žlabech sypký, hnědočerný sloupec hlíny (122). Žlaby byly vyhloubeny do sprašového podloží a černohnědé vrstvy 101, která pravděpodobně představovala původní svrchní vrstvu před výstavbou hradby. Hloubka vnějšího žlabu dosahuje přibližně $80 \mathrm{~cm}$, vnitřní až $\mathrm{k} 1 \mathrm{~m}$. Vnější i vnitřní žlab s palisádou byly nakonec zasypány a utěsněny sprašovou zeminou (124). V týlu byl vnitřní žlab, snad po zániku staršího opevnění, rozšířen vně a poté zaplněn rovněž vrstvou 124. Jádro starší hradby bylo zřejmě zaplněno vrstvou 119 (silně humózní zemina se spraší). Čelní zed' mladší hradby byla postavena na propálené vrstvě 123 se zuhelnatělým dřevem. Tato vrstva pravděpodobně představuje shořelou destrukci čela starší hradby. Jádro mladší hradby (vrstva 120) bylo tvořeno červenavou spraší a humózními hnědočernými pruhy, snad pozůstatky dřevěných roštů. Vrstva 120 zřejmě vypovídá o požáru mladší hradby (červenavé zbarvení). Destrukci týlu mladší hradby, která začíná asi 7,5 m od líce čelní zdi, tvoří kamenná destrukce (117) a hlinitá temně šedá vrstva promíšená kamením (125). Pod vrstvou 117 byly zachyceny pozůstatky dřev, snad relikty roštu. Čelní kamenná zed' (900) široká kolem 1 m byla zachována do výšky přibližně $1 \mathrm{~m}$. Berma vznikla na starší uložené vrstvě 101 a byla široká přibližně $3 \mathrm{~m}$. Po zániku hradby byla zasypána vrstvou červenavé spraše s kameny z čelní zdi (121). Pás kamenné destrukce z rozpadlé čelní zdi se dostal až na dno žlabovitého př́íkopu. Na bázi valového tělesa byl tento pás narušen snad recentním výkopem 126. Při rozpadu čelní zdi byl př́kop již částečně zanesen sprašovou vrstvou 130. Žlabovitý př́íkop, 2,5 m hluboký a 7,5 m široký, byl vyhlouben do sprašového podloží. 

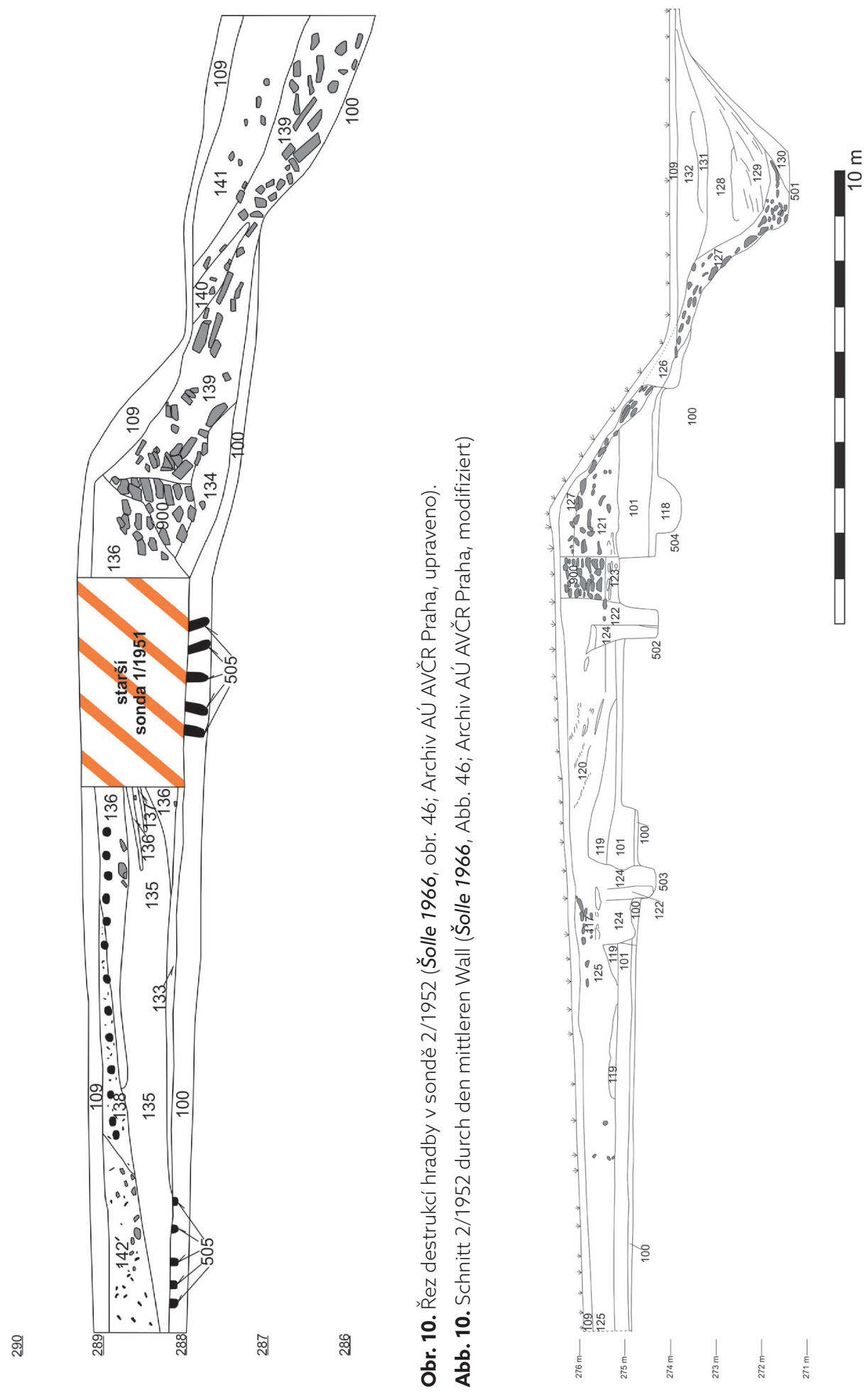

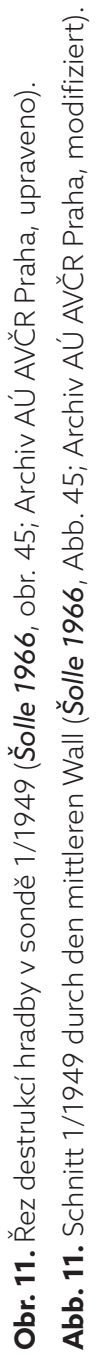




\begin{tabular}{|c|c|c|}
\hline Vrstva & Profil & Popis \\
\hline 100 & 1/1948, 1/1949, 2/1952 & Podloží - spraš, sprašová hlína. \\
\hline 101 & $1 / 1948,1 / 1949$ & $\begin{array}{l}\text { Černohnědá zemina, označeno jako „pưvodní svrchní vrstva před výstav- } \\
\text { bou hradby". }\end{array}$ \\
\hline 102 & $1 / 1948$ & Bělošedá jemná jílová vrstva. \\
\hline 103 & $1 / 1948$ & Žlutá patrně sprašová vrstva \\
\hline 104 & $1 / 1948$ & $\begin{array}{l}\text { Sprašová červenožlutá vrstva promíšená se zetlelým a spáleným dřevem } \\
\text { a s úzkými popelovitými žilkami. }\end{array}$ \\
\hline 105 & $1 / 1948$ & Žlutá vrstva, nejspíš sprašová. \\
\hline 106 & $1 / 1948$ & Úzká popelovitá vrstva. \\
\hline 107 & $1 / 1948$ & Žlutá vrstva, nejspíš sprašová, podobná vrstvě 105. \\
\hline 108 & $1 / 1948$ & Hnědá humózní zemina, obsahuje opálené kousky dřev. \\
\hline 109 & $1 / 1948,1 / 1949,2 / 1952$ & Ornice. \\
\hline 110 & $1 / 1948$ & Žlutá patrně sprašová vrstva. Podobná jako 103 a 105. \\
\hline 111 & $1 / 1948$ & Žlutavé a černavé vrstvy zásypu. \\
\hline 112 & $1 / 1948$ & Žlutavý zásyp rulového detritu. \\
\hline 113 & $1 / 1948$ & Šedožlutá vrstva. \\
\hline 114 & $1 / 1948$ & Silně kamenitá vrstva destrukce. \\
\hline 115 & $1 / 1948$ & Černohnědá zemina, podobného charakteru jako vrstva 101. \\
\hline 116 & $1 / 1948$ & Hnědá humusovitá vrstva. \\
\hline 117 & $1 / 1948,1 / 1949$ & Kamenná destrukce z týlní části hradby. \\
\hline 118 & $1 / 1949$ & Chybí popis. \\
\hline 119 & $1 / 1949$ & Silně humózní zemina, promíšená se spraší. \\
\hline 120 & $1 / 1949$ & Vrstva z humózních hnědočerných pruhů a červenavé spraše. \\
\hline 121 & $1 / 1949$ & Podobná vrstva jako 120, promíšená s kamennou destrukcí z čelní zdi. \\
\hline 122 & $1 / 1949$ & $\begin{array}{l}\text { Sypké, hnědočerné sloupce hlíny kolmo stojící ve žlebech. } \\
\text { Pozůstatky dřevěné palisády. }\end{array}$ \\
\hline 123 & $1 / 1949$ & $\begin{array}{l}\text { Červeně vypálená hlína s hustě vedle sebe kladenými zuhelnatělými } \\
\text { dřevci. }\end{array}$ \\
\hline 124 & $1 / 1949$ & $\begin{array}{l}\text { Jasně žlutý sprašový materiál, vsypaný do žlebů k vyztužení záporové } \\
\text { stěny. }\end{array}$ \\
\hline 125 & $1 / 1949$ & Hlinitá temně šedá vrstva promíšená kamením. \\
\hline 126 & $1 / 1949$ & Pravděpodobně recentní narušení kamenné destrukce z čelní zdi. \\
\hline 127 & $1 / 1949$ & Silně kamenitá vrstva destrukce z čelní kamenné zdi. \\
\hline 128 & $1 / 1949$ & Hlinitý zásyp př́kopu promíšený kameny. \\
\hline 129 & $1 / 1949$ & Hlinitý zásyp příkopu promíšený silněji humusem. \\
\hline 130 & $1 / 1949$ & Žlutohnědá vrstva sprašového původu. \\
\hline 131 & $1 / 1949$ & $\begin{array}{l}\text { Žlutohnědá vrstva sprašového původu, podobného charakteru jako } \\
\text { vrstva } 130 .\end{array}$ \\
\hline 132 & $1 / 1949$ & Vrstva sprašového původu (podobná jako 131) zesílená recentní orbou. \\
\hline
\end{tabular}




\begin{tabular}{|c|c|c|}
\hline Vrstva & Profil & Popis \\
\hline 133 & $2 / 1952$ & $\begin{array}{l}\text { Podle M. Šolla „pưvodní úroveň”, bez další charakteristiky. Pravděpodobně } \\
\text { vznikla v době užívání tzv. halové stavby (kulturní vrstva?). }\end{array}$ \\
\hline 134 & $2 / 1952$ & Chybí popis. \\
\hline 135 & $2 / 1952$ & Souvrství popela a spraše. \\
\hline 136 & $2 / 1952$ & Žlutohnědá sprašová vrstva. \\
\hline 137 & $2 / 1952$ & Chybí popis. \\
\hline 138 & $2 / 1952$ & Popelová vrstva s 1. a 2. vrstvou roštů. \\
\hline 139 & $2 / 1952$ & Šedá hlinitá zemina promíšená s kamennou destrukcí z čelní zdi. \\
\hline 140 & $2 / 1952$ & Detrukční vrstva s příměsí spraše. \\
\hline 141 & $2 / 1952$ & Detrukční vrstva s príměsí spraše podobného charakteru jako vrstva 140. \\
\hline Výkopy & Profil & Popis \\
\hline 500 & $1 / 1948$ & Hrotitý príkop. \\
\hline 501 & $1 / 1949$ & Žlabovitý príkop. \\
\hline 502 & $1 / 1949$ & Žlab pro palisádu v čele starší hradby. \\
\hline 503 & $1 / 1948,1 / 1949$ & Žlab pro palisádu v týlu starší hradby. \\
\hline 504 & $1 / 1949$ & Zaohloubený objekt s pravěkou keramikou. \\
\hline 505 & $2 / 1952$ & Sloupové jámy, pozůstatky stěn tzv. halové stavby. \\
\hline \multicolumn{3}{|c|}{ Zděné konstrukce } \\
\hline Zed' & Profil & Popis a interpretace \\
\hline 900 & 1/1948, 1/1949, 2/1952 & Čelní kamenná zed', nasucho kladená z místního rulového kamene. \\
\hline
\end{tabular}

Tab. 2. Přehled vrstev, výkopů a zdí zachycených v řezech 1/1948, 1/1949 a 2/1952.

Tab. 2. Der Übersicht der Schichte, Aushebungen und Mauern, die in Schnitten 1/1948, 1/1949 und 2/1952 aufgenommen wurden.

\subsection{Problematické situace a nové poznatky získané na základě revizního zpracování střední hradby}

\subsubsection{Starší hradba}

U starší fortifikace se podařilo rozpoznat především přináležející příkop a zároveň vyvstal š problém v nejasnosti průběhu starší hradební linie ve východní části Staré Kouřimi. Podle původní interpretace měl být příkop starší hradby z větší části zahrnut do širokého příkopu mladšího opevnění a nemohl být v plném rozsahu sledován (Šolle 1966, 101). Dále se autor výzku- mu bohužel starším příkopem již nezabýval. Po pečlivém prostudování plánů bylo zřejmé, že v sondě 1/1948 byl zachycen právě starší příkop. Mladší fortifikace se tu totiž odchyluje od průběhu starší hradby, hrotitý prríkop je od mladší hradby poměrně vzdálen (téměř 13 m; obr. 9) a očividně respektuje průběh staršího opevnění. Lze se tedy domnívat, že příkop zachycený sondou 1/1948 náleží právě starší hradbě (viz. výše). Při stavbě mladší fortifikace byl v tomto místě příkop nadále využit a jeho vrchní část rozšíŕena směrem k čelu hradby, a tím došlo $\mathrm{k}$ částečnému zplanýrování tělesa starší hradby. Podle řezu opevněním v sondě 
1/1948 byl starší příkop široký přibližně $9 \mathrm{~m}$ a hluboký 2,5 m (obr. 9; tab. 2).

Pozůstatky starší hradby byly odkryty jen východně od vrcholu Staré Kouřimi. Starší dřevohlinitá fortifikace je tak zachycená pouze ve východní části středního úseku a ve východním úseku. Západně od vrcholu návrší byl v sondách identifikován a ověřen již jen průběh mladší hradby a je tedy nejasné, kam dále směřovala starší fortifikace a jaký je důvod odchýlení mladší hradby.

\subsubsection{Tzv. halová stavba}

\subsubsection{Analýza nálezové situace}

Zvláštní útvar tzv. halová stavba byl zjištěn převážně pod tělesem mladší střední hradby v sondách 2/1950 F, 1/1951 A a 2/1952. V půdorysu tvořily stavbu dvě protáhlé prribližně rovnoběžné stěny tvořené vždy pěti řadami sloupů. Kratší strany na západě a východě byly nepravidelně oble vypouklé. Vysledovaný útvar dosahoval délky $89 \mathrm{~m}$, pokud připočteme obvodové stěny byl široký na západním konci přibližně $7 \mathrm{~m}$ a na východním konci asi $8,5 \mathrm{~m}$ (prostor v rámci obvodových stěn byl široký $4 \mathrm{~m}$ na západním konci a $6 \mathrm{~m}$ na východním konci). Zhruba uprostřed byl obvod nejširší a dosahoval až $10 \mathrm{~m}$. Dvě proluky v jižní stěně byly vysvětlovány jako vchody do tohoto útvaru. První sondou, kterou byl zkoumán prostor tzv. halové stavby byla sonda $2 / 1950 \mathrm{~F}$, tehdy však řady kůlových jamek ještě nebyly rozpoznány. V následujícím roce výzkum pokračoval západním a východním směrem (označeno jako sonda 1/1951 A) od předešlé sondy, kdy byly zjištěny „pásy kolových řad“. M. Šolle připustil zničení některých jamek v roce 1950 „z neznalosti a jejich velmi špatné rozpoznatelnosti“. Jamky byly zahloubeny pouze mělce do podloží a nelišily se barevně ale jen kyprostí výplně. Aby výzkum předešel dalšímu ničení objektů, byla $\mathrm{v}$ roce
1951 uplatněna metoda, jež spočívala v založení hladiny výzkumu výše než na rozmezí původního povrchu a podloží. Sonda 1/1951 převážně sledovala řady sloupových jamek, v prostřední části byl půdorys odkryt celý (Šolle 1952, 7-9). Vnitřní část půdorysu stavby na západním a východním konci byla prokopána až v následujícím roce sondou 2/1952, kdy byla odkryta většina zahloubených objektů. Při srovnání půdorysu sondy 2/1950 F a půdorysu tzv. halové stavby z let 1951 a 1952 bylo patrné, že v místě odkryvu 2/1950 $\mathrm{F}$ v pozdější situaci přibyly pozůstatky severní a jižní obvodové stěny tzv. halové stavby, a to pod kumulacemi kamenů, zachycených v roce 1950. Zřejmě tyto obvodové jamky nebyly v roce 1950 ještě zasaženy a byly odkryty až v roce 1951, kdy se k sondě 2/1950 F po zjištění obvodového pásu výzkum vrátil a následně byly i zde pásy odkryty. Tato skutečnost by mohla vypovídat o tom, že ne všechny sondy na Staré Kouřimi musely být zcela dokopány. Za zmínku stojí i skutečnost, že některé zahloubené objekty, které byly narušeny obvodovým pásem tzv. halové stavby, nebyly $\mathrm{v}$ půdorysu sondy 1/1951a vyznačeny, pravděpodobně však byly těžko přehlédnutelné, zatímco v celkovém odkryvu z roku 1952 je znát již jejich průběh i pod těmito pásy, jedná se například o objekty $3 / 52,7 / 52,13 / 52$.

V prostoru tzv. halové stavby bylo, kromě hrobových jam kultury se šňůrovou keramikou, odkryto několik zahloubených objektů charakteru sídlištního (Šolle 1951, 17; 1952, 17-18; $1966,232-234)$. Některé z těchto objektů byly datovány do období eneolitu (2/51,3/51, 3/52) a do doby mladšího pravěku (13/52). Objekty zařaditelné do raného středověku byly vyčleněny jako starší než tzv. halová stavba $(1 / 50$, $2 / 50,4 / 52,7 / 52,12 / 52)$ a objekty současné se stavbou $(1 / 52,2 / 52,5 / 52,6 / 52,8 / 52,9 / 52$, $10 / 52,11 / 52)$. V prostoru byly odkryty také objekty bez nálezů, a tedy i bez jasného časového zařazení. 
Jáma 1/50: kruhový půdorys, $100 \times 70 \mathrm{~cm}$, hloubka $60 \mathrm{~cm}$, trychtýřovitě se zužující, dno ploché, humózní výplň. Překryta stěnou halové stavby.

Jáma 2/50: podlouhlá, oválná jáma s nerovným výškově členitým dnem se stěnami nálevkovitě rozšířenými, humózní hlinitá výplň, rozměry 300x150 cm, hloubka $80-90 \mathrm{~cm}$, nálezy: raně středověká keramika (obr. 12:1).

Těsně vedle jámy 2/50 západně od ní neoznačená kruhová jáma, rozměry $120 \times 130 \mathrm{~cm}$, hloubka $112 \mathrm{~cm}$. Bez nálezů.

Jáma 2/51: zásobnicová, pravidelně zakroužená kotlovitá jáma s široce kuželovitým dnem s drobnými kolíky na obvodu, spojená s mělčí prostornější jámovou prohlubní. Hloubka zásobnicové jámy $70 \mathrm{~cm}$, hloubka prohlubně $50 \mathrm{~cm}$. Pod jižní stěnou halové stavby. V zásypu objektu eneolitická keramika a jeden velký fragment raně středověké nádoby. Nálezy se nepodařilo dohledat, je však alespoň zachycena v obrazových tabulkách v nálezové zprávě (Šolle 1951, tab. 60-62). Jáma byla interpretovaná jako eneolitická.

Jáma 3/51: menší jáma, zachyceno její dno. Pod jižní stěnou tzv. halové stavby. Obsahuje eneolitickou keramiku a pazourkové čepele. Nálezy se nepodařilo dohledat. Jeden větší kus zásobnicové nádoby byl zachycen v obrazových tabulkách v nálezové zprávě (Šolle 1952, tab. 63). Jáma byla interpretovaná jako eneolitická.

Jámy 1/52: a 2/52: Dvě jámy pravděpodobně vzájemně provázané. Obě jsou oválné s kónickými, mírně prohnutými stěnami a plochým dnem, šedá výplň. Rozměry jámy $1 / 52$ $370 \times 170 \mathrm{~cm}$ a jámy $2 / 52430 \times 105$, hloubka jam 23 až $26 \mathrm{~cm}$. Obsahovaly v popelovité výplni raně středověkou keramiku a zviŕrecí kosti.

Jáma 3/52: obdélníkový objekt se zaoblenými rohy, členěn v jámu a „kruhové ohniště“ vybíhající z obrysu obdélníkové jámy. Jáma má ploché dno a kónické, miskovité stěny. Částečně pře- kryta jižní stěnou halové stavby. Podle popisu měly být v jámě nalezeny raně eneolitická a raně středověká keramika. „Ohniště“ silně vypálené do červena, vyplněno kamením vystupuje nad dno ostatní jámy, obsahuje jen „eneolitickou keramiku“ a výrazné kusy mazanice s otisky proutí. Jím byla celá jáma datována do eneolitu. Při kontrole materiálu však vyvstává problém s datací objektu. Nalezena byla jen keramika raného středověku (obr. 12:2) a při srovnání popisu keramiky ze seznamu nálezů v nálezové zprávě jiná, než raně středověká keramika nebyla uvedena. Nálezy z „ohniště“ obsahovaly kromě čtyř kusů mazanice a jednoho kusu křemene jeden zlomek keramiky - nezdobené dno nádoby. Podle keramické hmoty, která je podobná s raně středověkou keramikou z lokality, lze toto dno zařadit pravděpodobně do produkce raného středověku. Zmíněná eneolitická keramika nebyla nalezena ani v seznamu nálezů ani sáčku s nálezy. Domnívám se tedy, že tuto jámu lze spíše označit jako raně středověkou než eneolitickou.

Jáma 4/52: kruhová, kónické stěny, dno nepatrně členité, rozměry $150 \times 120 \mathrm{~cm}$, hloubka 40 $\mathrm{cm}$. Tmavě šedohnědá hlinitá výplň. Nacházela se těsně u jižní stěny halové stavby. Obsahovala zlomky raně středověké keramiky.

Jámy 5/52 a 6/52: Dvě jámy pravděpodobně vzájemně provázané. Jáma $5 / 52$ je obdélně členěná $(330$ × 230, hloubka 22-23 cm), jáma 6/52 (440 × $240 \mathrm{~cm}$, hloubka $18-50 \mathrm{~cm})$ má pravidelný obdélníkový půdorys se zaoblenými rohy. Stěny jsou trychtýřovitě rozevřené, dno ploché se sloupovými jamkami. Výplň šedá, popelovitá. Obsahují raně středověkou keramiku (obr. 12:11).

Jáma 7/52: kruhová, miskovitá, rozměry 110$120 \mathrm{~cm}$, hloubka $19 \mathrm{~cm}$, popelovitá výplň.

Zahlubuje se pod jižní stěnu tzv. halové stavby. Jáma sloužila jako topeniště. Raně středověká keramika. 
Jáma 8/52: nepravidelný oválný obrys s výběžkem na západní straně, rozměry $500 \times 340 \mathrm{~cm}$, hloubka $8 \mathrm{~cm}$ a hloubka výběžku $30 \mathrm{~cm}$. Členěna $\mathrm{v}$ jámu horní a spodní a pokryta řadou drobných sloupových jamek snad z konstrukce opevnění. Šedohnědá hlinitá výplň, obsahuje raně středověkou keramiku (obr. 12:4, 5, 7). Při východní straně jámy $8 / 52$ dvě větší sloupové jamky $(80 \times 50$, hloubka $25 \mathrm{~cm} ; 65 \times 35$ $\mathrm{cm}$, hloubka $23 \mathrm{~cm}$ ) a jedna žlabovitá jáma $(140 \times 40 \mathrm{~cm}$, hloubka $11 \mathrm{~cm})$ bez výrazné výplně a keramiky.

Komplex jam 9/52 - 11/52: Nejhlubší a nejvýraznější jámy s obsahem raně středověkým (obr. 12: 3, 6, 9-10, 13-15).

Jáma 9/52: menší jáma s kónickými nálevkovitě rozevřenými stěnami, ploché dno, rozměry $156 \times 100 \mathrm{~cm}$, hloubka $46 \mathrm{~cm}$. Hlinitá slabě humózní výplň. Kromě keramiky byl nalezen drobný nezdobený gombík (Šolle 1966, obr. LI:7), nález se nepodařilo dohledat.

Jáma 10/52: miskovitě rozevřená, ploché dno, rozměry $325 \times 152 \mathrm{~cm}$, hloubka $77 \mathrm{~cm}$. Hlinitá slabě humózní výplň. $\mathrm{Z}$ jámy pocházejí nálezy raně středověké keramiky a zlomek kamenné sekerky ze staršího pravěku.

Jáma 11/52: nálevkovitá jáma ostře kónické stěny, ploché dno, rozměry $220 \times 180 \mathrm{~cm}$, hloubka $118 \mathrm{~cm}$. Hlinitokamenitá výplň. Kromě raně středověké keramiky byl nalezen drobný skleněný gombík s měděným klínkem k zavěšení (Šolle 1966, obr. LI:6) nález se nepodařilo dohledat.

Jáma 12/52: mělčí miskovitá, oválná jáma, rozměry $170 \times 150 \mathrm{~cm}$, hloubka $55 \mathrm{~cm}$, narušena průběhem jižní stěny halové stavby. Šedohnědá hlinitá výplň. Z jámy pochází raně středověká keramika.

Jáma 13/52: Velká podlouhlá jáma ve východní polovině halové stavby. Porušuje jižní stěnu této „stavby“. Jáma byla označena jako „knovízská“ podle keramiky zařaditelné do mladšího pravě- ku (mladší až pozdní doba bronzová nebo doba halštatská). Obsahuje však i raně středověkou keramiku (10 střepů, obr. 12:8, 12), které má výrazně vyšší podíl, něž keramika pravěká (3 střepy). Domnívám se tedy, že datování objektu do doby knovízské je sporné a může se jednat spíše o raně středověký objekt.

Objekty zařazené jako současné s halovou stavbou se nacházejí výhradně v její východní polovině. V těchto objektech byly spatřovány 4 skupiny jam v pravidelných vzdálenostech od sebe. Jámy byly povětšinou mělké mísovité, jen „komplex“ jam 9/52, 10/52, 11/52 dosahoval hloubky 70-100 cm. V tomto ohledu vznikl předpoklad rozdělení halové stavby na dvě poloviny s rozdílnými funkcemi. Západní polovina měla být plochá, zatímco ve východní polovině byly zahloubené objekty (Šolle 1966, 109-119). Objekty současné se stavbou se nacházejí jen ve východní polovině půdorysu. Všechny údajně starší raně středověké objekty byly porušeny obvodovou stěnou. Pouze objekt 2/50 v západní polovině půdorysu stavby se nacházel v jejím interiéru, vztah objektu se stavbou byl však odmítnut vzhledem k pravděpodobné příslušnosti s objektem $1 / 50$, který byl porušen obvodovou stěnou stavby. Objekty 3/52 a 13/52, které byly určeny do staršího pravěku je možno s velkou pravděpodobností na základě nálezového materiálu (obr. 12:2, 8, 12) zařadit do raného středověku. Je třeba poznamenat, že keramika $\mathrm{z}$ objektů považovaných za starší, než stavba (obr. 12:1, 2, 8, 12) má podobné rysy jako keramika z objektů údajně mladších (obr. 12:3-7, 9-11, 13-15). Keramiku je možno zařadit do 9. století a do druhé poloviny 9. až první poloviny 10. století. Souvislost zahloubených objektů se stavbou tak není zcela prokazatelná a funkční dělení stavby na západní plochou - sněmovní část a východní obytnou část se zahloubenými objekty lze zpochybnit. 

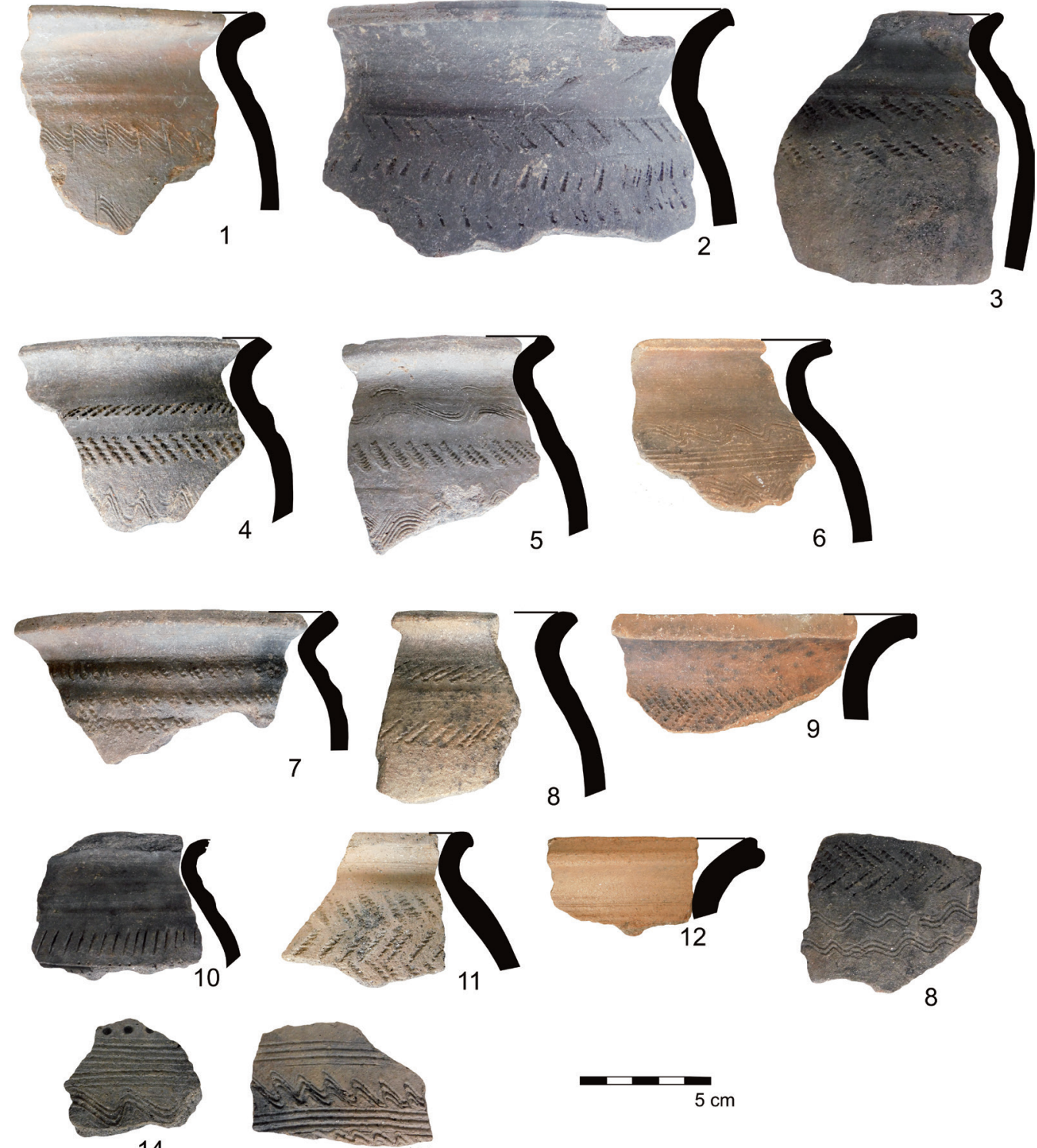

15

Obr. 12. Výběr keramiky z objektů „pod tzv. halovou stavbou”. 1: obj. 2/50; 2: obj. 3/52; 3, 6, 9-10, 13-15: obj. 9-12/52; 4-5, 7: obj. 8/52; 8, 12: obj. 13/52; 11: obj. 6/52.

Abb. 12. Eine Auswahl der Keramik aus "der Gruben unter dem sog. Hallenbau". 1: Befund 2/50; 2: Befunden 3/52; 3, 6, 9-10, 13-15: Befunden. 9-12/52; 4-5, 7: Befunden 8/52; 8, 12: Befund 13/52; 11: Befund 6/52. 


\subsubsection{Mladší hradba}

Mladší hradba byla zjištěna ve všech třech úsecích průběhu destrukce středního opevnění s výjimkou východní poloviny středního úseku, kde byla již značně rozoraná a kde se zachovaly jen pozůstatky starší fortifikace. Čelní kamenná zed' hradby byla lícovaná jen z vnější strany a její šířka dosahuje hodnoty kolem jednoho metru. Výztuž hradby zajištovaly dřevěné rošty ${ }^{5}$, které musely být z důvodu stability zaklesnuty do čelní kamenné zdi, či jí procházet až k líci. M. Šolle předpokládal, že překládkový zpơsob kladení roštů byl použit v konstrukci v nejvyšší poloze návrší, na kterou mylně zasazoval akropoli, zatímco ve zbylých částech průběhu opevnění měl být použit jednosměrný rošt (Šolle 1966, 175). J. L. Píč popsal výkop opevnění v západním úseku, kde odkryl zuhelnatělé podélné a příčné trámce (Pič 1907, 524-525). V sondě 1/1956 ve stejném úseku bylo zachyceno spolu s první vrstvou roštů směřujících k čelní kamenné zdi jedno břevno kladené kolmo $\mathrm{k}$ nim, mohlo se jednat o druhou vrstvu roštů, podélný trám však mohl sloužit i jen jako pokládková vrstva příčných roštů. $\mathrm{V}$ ostatních sondách byly rošty zjištěny těsně pod povrchem a je možné, že se ostatní kolmé rošty již nedochovaly. Lze uvažovat, že překládkový zpơsob byl použit v celém průběhu mladší hradby, což by výrazně zvyšovalo její samosvornost. $\mathrm{V}$ př́ípadě úseků dělených příčnými liniemi kamenů a dřevěných prvků, které byly interpretované jako pozůstatky komor, se vzhledem ke konstrukčním detailům i rozměrům úseků mohlo jednat spíše o pozůstatky technických etap výstavby opevnění, podobně jako je tomu na Libušíně ${ }^{6}$ V destrukci týlní části se vyskytují kameny menších rozměrů a spálené vrstvy. Týl hradby mohl být tvořen těsným kladením dřev výztuže překládkovým způsobem ve vertikálním směru ${ }^{7}$. Kameny z destrukce mohly vyplňovat volný prostor mezi rošty, vznikla tedy jakási zídka nahrazující plnohodnotnou zadní zed'. V podstatě však šlo rov- něž o zed' proloženou rošty, která musela být souvislá, jinak by se zemina vyplavovala, pokud tomu nebránily rošty $\mathrm{v}$ podélném směru. Ke stanovení šířky hradby by bylo zapotřebí znát její hraniční prvky - vnější a vnitřní linii hradby. $\mathrm{S}$ jistotou známe pouze vnější, a to líc čelní kamenné zdi. Bohužel se tak musíme spokojit jen s minimální šířkou hradby, která byla určena z porovnání vzdálenosti mezi lícem čelní kamenné zdi a destrukcí týlní části. Tato hodnota se pohybuje kolem 7,5 m a v nejvyšší části návrší rozsah sahá až k 9,5 m. Výšku hradby nelze odhadnout, především vlivem rozorání značné části její destrukce. Berma měřila od líce hradby k prríkopu přibližně $3 \mathrm{~m}$. Kompletní řez příkopem byl zachycen v sondě 1/1949 ve východním úseku (obr. 11; tab. 2). Přríkop měl žlabovitý profil, dosahoval 2,5 m hloubky a 7,5 m šířky.

Jak již bylo poznamenáno výše, v sondách 1/1948 a 3/1952A byla odkryta situace, jež zachytila odchýlení mladší hradby od průběhu starší fortifikace (obr. 3a, 3b). V době současné s mladší hradbou byl zřejmě starší hrotitý příkop využit i nadále, byl však rozšîréen při svém horním vnitřním okraji zářezem širokým asi $9 \mathrm{~m}$. Před mladší hradbou tak vznikla bariéra zahrnující starší příkop a jeho rozšsiřrení, která byla široká až $19 \mathrm{~m}$ a hluboká ode dna hrotitého staršího příkopu až 5,5 m. Na základě přítomnosti spálených vrstev v jádru hradby (vrstvy 106, 120, 138) v destrukcích týlní části je pravděpodobné, že i mladší hradba zanikla požárem.

Do budoucna by bylo přínosné se zaměřit i na vnější opevnění, které je dosud interpretováno jako jednofázové (Šolle 1966, 102-104). Řez jeho destrukcí se nápadně podobá situaci vnějšího opevnění v Praze-Královicích, kde byla zjištěna dvoufázová hradba (Štefan - Hasil 2014). Je možné, že i destrukce starokouřimského vnějšího opevnění v sobě stále skrývá nerozpoznanou mladší fázi hradby snad s čelní kamennou zdí, 
o jejíž prrítomnosti by mohla vypovídat kamenná sut’ v příkopu. Tuto hypotézu však bude potřeba časem důkladně prověřit.

\section{Závěr}

Revizním zpracováním výzkumu střední hradby na Staré Kouřimi se podařilo zjistit několik nových poznatků a upřesnění, z nichž hlavní můžeme shrnout následovně:

1) Hrotitý příkop odkrytý v sondě $1 / 1948$, který M. Šolle považoval za př́kop mladší hradby náležel již ke starší hradbě.

2) Podle M. Šolla byly v mladší hradbě jen v nejvyšší poloze návrší přítomny překládkové rošty, zatímco ve zbytku této fortifikace byly rošty příčné. Podle výše zmíněných argumentů mohl však být překládkový rošt použit v celé konstrukci mladší hradby.

3) Podobně jako starší hradba také mladší hradba nejspíš zanikla požárem.

4) Zahloubené objekty pod tzv. halovou stavbou řazené do pravěku, které shodou okolností půdorys stěn halové stavby porušovaly patřily podle nálezového materiálu do raného středověku. Rovněž ostatní raně středověké objekty nelze dávat do souvislosti s tzv. halovou stavbou. Lze tedy zpochybnit funkční dělení stavby na západní (sněmovní) a východní (obytnou) část.

I přes značné narušení destrukce střední hradby přinesl její výzkum důležité poznatky, které nepochybně přispívají k jasnějšímu obrazu raně středověké Staré Kouřimi. Zásadní otázka, která vyvstala z revizního zpracování a kterou by bylo vhodné vyřešit, je, kam pokračovala starší hradba západně od vrcholu návrší a z jakého důvodu se mladší hradba odchyluje od starší hradby. $\mathrm{K}$ jejímu zodpovězení by nám mohl pomoci geofyzikální průzkum, který snad bude v budoucnu aplikován. Je nepochybné, že Stará Kouřim skrývá další radu problémů, které $\mathrm{s}$ dalším revizním zpracováním vyvstanou a které bude rovněž třeba řešit. Je třeba si ale uvědomit i skutečnost, že většinou ani revizním zpracováním na základě dochované dokumentace nezjistíme skutečný stav věcí, pouze je možné na jejím základě zpochybnit původní interpretace. Pokud by bylo možné v budoucnu provést revizní terénní výzkum, mohl by přinést zcela jiný obraz podoby, více fázovosti a snad i chronologie jednotlivých kouřimských hradeb.

1) Text je výtahem z diplomové práce obhájené na FF UK (Dvořáček 2017).

2) K rozvážení destrukce středního opevnění nám ve svém popisu Staré Kouřimi zanechal svědectví kouřimský učitel J. Kremla: „Val ten byl již v dřívějších dobách rozvážen, ale směr jeho dosud dobře sledovati lze. Nejlépe znáti jeho část jihovýchodní, pak na východ od kapličky, kde vrchol návrší $292 \mathrm{~m}$ n.m. se nachází, a konec západní. Loni při upravování pole u kapličky č.p. 876 přišlo se na zuhelnatělý dubový trám asi $20 \mathrm{~m}$ dl., který těsně vodorovně ku vnitřní straně valu přiléhal. O něco dále $\mathrm{k}$ jihu byla čtyřhranná popelovitá jáma přes $2 \mathrm{~m}$ široká vyplněná popelem a mezi nimi kosti zviŕecí a střípky typu hradištního patrně ohniště ze stavení, které tam stávalo“ (Kremla 1903, 396). Z jeho popisu je zřejmý i nález čelní kamenné zdi při bráně do středního areálu: „při skopávání pole v sev. cípu u pole č.p. 763, těsně při valu přišlo se na jakési zbytky zdi složené z plochých kamenů, maltou nespojených, kteréž silně kalcinovány byly, což o staletém ležení v zemi svědčí“ (Kremla 1903, 397).

3) Údaj M. Šolla (1966). Mnou naměřená délka střední hradby v programu ags.cuzk.cz/dmr/ je 970 až 990 $\mathrm{m}$ a liší se od údaje M. Šolla $820 \mathrm{~m}$ až o $170 \mathrm{~m}$. Délky opevnění by bylo vhodné přeměřit př́mo v terénu. 
4) Délky jednotlivých úseků destrukce středního opevnění jsem určil měřením z lidarového snímku na internetových stránkách ags.cuzk.cz/dmr/, délky uvádím v přibližných hodnotách, bylo by třeba je přeměřit přímo v terénu.

5) Podle fytopaleontologického rozboru provedeného v sondě 1/1956 se jednalo především o dubové dřevo (Šolle 1957, 26).

6) Za upozornění na tento problém děkuji Mgr. L. Varadzinovi, Ph.D.

7) Na problematiku, že ne všechny kamenné destrukce v týlních částech hradeb lze interpretovat jako pozůstatky zadních kamenných zdí upozornil na příkladě Tašovic L. Kos a uvedl, že kameny z těchto destrukcí mohly sloužit také k utěsnění zadních dřevěných stěn (Kos 2012, 136).

\section{Bibliografie}

Bartošková, A. 2014: Budeč. Významné mocenské centrum prvních Přemyslovců. Praha.

Boháčová, I. 2001: Pražský hrad a jeho nejstarší opevňovací systémy. Medievalia archaeologica 3, Pražský hrad a Malá Strana. Praha, 179-301.

Dresler, P. 2011: Opevnění Pohanska u Břeclavi. Brno.

Dvoŕáček, D. 2017: Stará Kouřim-revize vybraných úseků archeologického výzkumu M.

Šolla. Nepublikovaná diplomová práce. Filozofická fakulta, Univerzita Karlova. Praha.

Hladik, M. a kol. 2014: Fortification of the suburb of the Great Moravian stronghold at Mikulčice-Valy. Slavia Antiqua LV, 67-124.

Kalčik, L. 2015: Povelkomoravské osídlení hradiska Staré Zámky u Líšně. Přehled výzkumů 56, 127-200.

Kos, L. 2012: Raně středověké fortifikace s čelní kamennou plentou ve střední Evropě. Studia mediaevalia Pragensia 11, 117-175.

Kristián: Kristiánova legenda. Život a umučení svatého Václava a jeho báby svaté Ludmily (Legenda Christiani. Vita et passio sancti Wenceslai et sancte Ludmile ave eius), ed. J. Ludvíkovský, Praha 1978.

Kremla, J. 1903: Předhistorická hradiště v okresu kouřimském. Památky archeologické XX, 395-406, tab. XLII-XLIV.

Mazuch, M. 2014: Findings about the early medieval fortification of the Mikulčice - Valy acropolis. Slavia Antiqua LV, 7-65.

Pelikán, J. B. - Vojáček, V. 1956: Pedochemický výzkum na Staré Kouřimi. Referáty o pracovních výsledcích čsl. archeologů za rok 1955, 7-14.

Pič, J. L. 1907: Z výzkumu našich hradište. Památky archeologické XXII, 519-532.

Procházka, R. 2009: Vývoj opevňovací techniky na Moravě a v českém Slezsku v raném středověku. Brno.
Šolle, M. 1949: Stará Kouřim. Nálezová zpráva o výzkumu v r. 1948. Archiv ARÚ AV ČR, čj. 5645/49.

Šolle, M. 1950: Stará Kouřim. Nálezová zpráva o výzkumu v r. 1949. Archiv ARÚ AV ČR, čj. 1667/50.

Šolle, M. 1951: Stará Kouřim. Nálezová zpráva o výzkumu v r. 1950. Archiv ARÚ AV ČR, čj. 1499/51.

Šolle, M. 1952: Stará Kouřim. Nálezová zpráva o výzkumu v r. 1951. Archiv ARÚ AV ČR, čj. 1518/52.

Šolle, M. 1953a: Stará Kouřim. Nálezová zpráva o výzkumu v r. 1952. Archiv ARÚ AV ČR, čj. 2382/53.

Šolle, M. 1953b: Staroslovanská dvojitá brána na Staré Kouřimi a její restaurace. Památky archeologické 44, 347-363.

Šolle, M. 1954: Stará Kouřim. Nálezová zpráva o výzkumu v r. 1953. Archiv ARÚ AV ČR, čj. 59/54.

Šolle, M. 1956: Stará Kouřim. Nálezová zpráva o výzkumu v r. 1955. Archiv ARÚ AV ČR, čj. 2839/58.

Šolle, M. 1957: Stará Kouřim. Nálezová zpráva o výzkumu v r. 1956. Archiv ARÚ AV ČR, čj. 5685/57.

Šolle, M. 1959: Knížecí pohřebiště na Staré Kouřimi. Památky archeologické 50, 353-506.

Šolle, M. 1966: Stará Kouřim a projevy velkomoravské hmotné kultury v Čechách. Praha.

Šolle, M. 1969a: Kouřim v mladší a pozdní době hradištní. Památky archeologické LX, 1-124.

Šlle, M. 1969b: Tor und Turm bei den Westslawen in frühgeschichtlicher Zeit. In: K. H. Otto-J. Herrmann (Hrsg.), Siedlung, Burg und Stadt. Berlin, 219-231.

Šolle, M. 1993: Přemyslovská a děpoltická Kouřim podle výzkumu z let 1967-77. Archeologické rozhledy 45, 268-278, 360-362.

Štefan, I. - Hasil, J. 2014: Raně středověké hradiště v Praze Královicích. Archeologické rozhledy 66, 453-492.

Varadzin, L. 2012: Raně středověké hradiště Libušín. Hlavní poznatky z revizního zpracování výzkumů. Archeologické rozhledy 64, 723-774. 


\section{Die Revisionsbearbeitung des mittleren Walles von Alt Kouřim}

Der Burgwall Alt Kouřim im östlichen Teil Mittelböhmens erlebte seine Blütezeit vor allem in der zweiten Hälfte des 9. Jh. bis ins erste Drittel des 10. Jh. Mit einem umwehrten Areal von 44,2 ha Größe, zählt die Anlage zu den größten Burgwällen Mitteleuropas. In den Jahren 1948 bis 1957 wurden hier großflächige Ausgrabungen unter der Leitung von Dr. Miloš Šolle (Archäologisches Institut ČSAV) durchgeführt. Šolle veröffentlichte die hauptsächlichen Ergebnisse seiner Arbeit in der Monografie „Alt Kouřim und die großmährische Kultur in Böhmen“ (Šolle 1966). Im Rahmen einer neuerlichen Aufarbeitung von Šolles Grabungen, werden im vorliegenden Artikel erste Ergebnisse zum mittleren der drei Befestigungslinien der Burganlage vorgestellt.

Der mittlere Wall (Abb. 3a, b) mit seinen ca. 820 $m$ Länge stellt den am ausgiebigsten ergrabenen Teil der Befestigungen dar, er wurde jedoch in der Neuzeit durch landwirtschaftliche Tätigkeiten stark gestört und zahlreiche Steine geplündert. Durch die Ausgrabungen konnten zwei Bauphasen festgestellt werden - ein älterer und ein jüngerer Wall. Der ältere Wall bestand in einer Holz-Erde Konstruktion in Schalenbauweise, wobei zwei Palisadenwände, die vermutlich durch Holzanker miteinander verbunden waren, errichtet wurden (Abb. 5). An den AuBenseiten wurden beide Palisadenwände zusätzlich durch schräge Streben gestützt. Zu dieser Zeit wurde wahrscheinlich auch ein Graben vor dem Wall ausgehoben, der in der anschließenden jüngeren Phase erweitert und umgestaltet wurde. In einer scharfen Biegung des Walles befand sich die Toranlage (Abb. 4, 5). Mit dieser älteren Befestigung war der sog. Hallenbau eng verknüpft. Hierbei handelte es sich um einen an der höchsten Stelle des umwehrten Areals situierten ungewöhnlichen Bau (89 m lang), der vielleicht für Versammlungen genutzt wurde. Innerhalb dieses Baus entdeckte man eine Gruppe von Gruben (Abb. 6). Ins Frühmittelalter datierten nur diejenigen, die im östlichen Teil der Halle situiert waren und vielleicht als „Keller“ verwendet wurden.
Die übrigen Gruben wurden in die Urgeschichte datiert und das Errichten des Hallenbaus über ihnen als Zufall bewertet. Der ältere Wall und der sog. Hallenbau fanden in einem Brand ihren Untergang. Nach diesem Ereignis errichtete man einen neuen Holz-Erde-Wall, diesmal mit Vordersteinmauer. Der Wall wurde in stufenförmiger Bauweise und mit Hintersteinmäuerchen rekonstruiert (Abb. 7). Der Wall wurde noch von horizontalem Rosten verstärkt. Der vorm Wall liegende Graben war bis zu 4,5 m tief und bis $9 \mathrm{~m}$ breit.

Im Licht der neuen Revisionsbearbeitung, scheinen einige Hypothesen Šolles zu den Bauphasen des mittleren Walls mehr als unsicher. Der Spitzgraben, der im Schnitt 1/1948 entdeckt wurde (Abb. 9) und der jüngern Phase zugeordnet wurde, gehört mit großer Sicherheit zum älteren Wall. Der ältere Graben ist in diesem Bereich (Schnitt 1/1948) erhalten, da er hier einen anderen Verlauf aufweist als der jüngere Graben, und sich beide Anlagen daher nicht überlagern. Von Schnitt 1/1948 aus ist der Verlauf der älteren Fortifikation in östliche Richtung bis heute unbekannt (Abb. 3b). Die Gruben unter dem sog. Hallenbau, die man in urgeschichtliche Zeit datierte, enthalten außer einigen prähistorischen Scherben größtenteils frühmittelalterliche Keramik (Abb. 12), die der aus den anderen frühmittelalterlichen Gruben weitgehend entspricht. Die Gruben hingenwahrscheinlich nicht mit dem sog. Hallenbau zusammen. Der jüngere Wall wurde durch den Sohlgraben geschützt (Abb. 11). Die Steinverfüllung, die man als Rest des Hintersteinmäuerchens in der jüngeren Befestigung betrachtete, könnte zwischen dem Holzrost als Steinabdichtung gegen das Abschwemmen der Erde aus dem Wall gedient haben. Darüber hinaus sind auch in der jüngeren Befestigung Spuren einer Brandzerstörung erkennbar. Etwa um die Hälfte des 10. Jh. fiel Alt Kouřim wüst und wurde im 11. Jh. als neuer Zentralort durch eine befestigte Spornanlage mit Kirche St. Georg in direkter Nachbarschaft ersetzt. 


\section{Mgr. Daniel Dvořáček}

- Ústav archeologie a muzeologie,

Filozofická fakulta, Masarykova univerzita,

A. Nováka 1, 60200 Brno, Česká republika

489426@mail.muni.cz 